\title{
Atomic Fe Dispersed Hierarchical Mesoporous Fe-N-C Nanostructures for Efficient Oxygen Reduction Reaction
}

\footnotetext{
Yu Zhou ${ }^{+, \ddagger}$, Yanan $\mathrm{Yu}^{+, \neq}$, Dongsheng $\mathrm{Ma}^{\ddagger}$, Alexandre C. Foucher ${ }^{\S}$, Lei Xiong ${ }^{\ddagger}$, Jiahao Zhang ${ }^{\ddagger}$, Eric A. Stach ${ }^{\S}$, Qin Yue $^{*}$, , and Yijin Kang ${ }^{*}, \neq$

${ }^{\ddagger}$ Institute of Fundamental and Frontier Science, University of Electronic Science and Technology of China, Chengdu 610054, China

$\S$ Department of Materials Science and Engineering, University of Pennsylvania, Philadelphia, Pennsylvania 19104, United States
}

*Corresponding authors:

qinyue@uestc.edu.cn

kangyijin@uestc.edu.cn

This PDF file includes:

Experimental Section

Figure S1-S20

Table S1-S3 


\section{Table of Content}

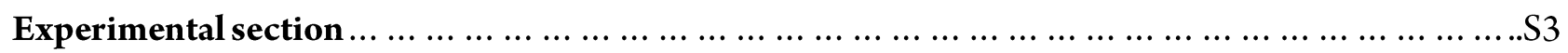

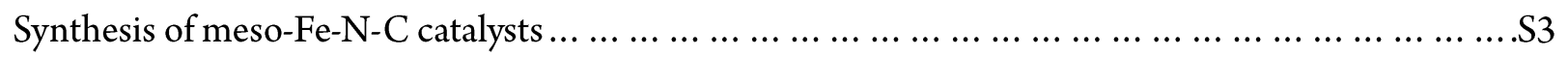

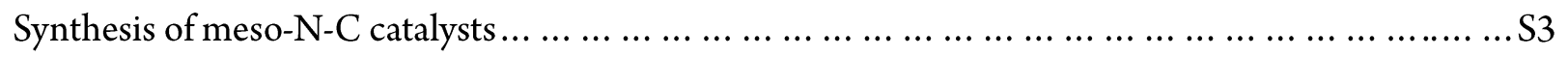

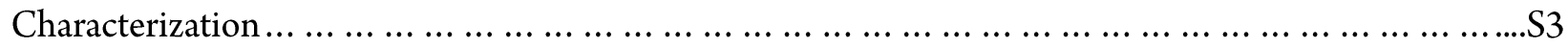

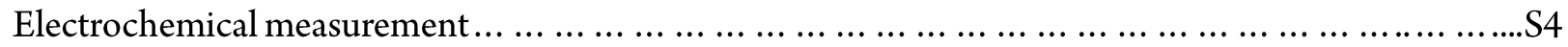

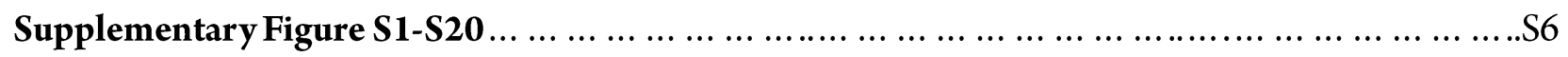

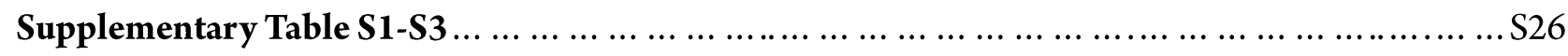

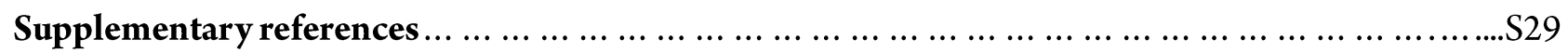




\section{EXPERIMENTAL SECTION}

\section{Synthesis of meso-Fe-N-C catalysts}

The preparation of a series of meso-Fe-N-C catalysts was based on the nano-emulsion assembly approach, ${ }^{1,2}$ which is illustrated in Scheme 1 . For a typical meso-Fe-N-C synthesis process, Pluronic F127 (1.0 g, Sigma-Aldrich) and dopamine hydrochloride (DA, 0.5 g, 99\%+, Adamas Reagent) were dissolved in the mixture of ethanol $(50 \mathrm{~mL}$, General Reagent) and deionized water (DI water, $50 \mathrm{~mL})$ by ultrasonication. $\left(\mathrm{NH}_{4}\right)_{2} \mathrm{Fe}\left(\mathrm{SO}_{4}\right)_{2} \cdot 6 \mathrm{H}_{2} \mathrm{O}($ $\geqslant 99.5 \%$, General Reagent) was added into the mixture to form a solution of $0.1 \mathrm{mmol} \mathrm{L}^{-1}$. Subsequently, 1,3,5-trimethylbenzene (TMB, $2.0 \mathrm{~mL}, 99 \%+$, Adamas Reagent) was gradually added into the solution under continuous stirring ( $500 \mathrm{rpm}$ ) for 30 minutes to form a nano-emulsion system. After that, the concentrated ammonia $\left(\mathrm{NH}_{4} \mathrm{OH}, 5.0 \mathrm{~mL}, 28 \mathrm{wt} \%\right.$, Hushi Reagent) was dropwise added to the solution. After stirring for another $30 \mathrm{~min}$, Fe/PDA/F127 composites were produced. The products were collected by centrifugation ( $9000 \mathrm{rpm}$ for $10 \mathrm{~min}$ ) followed by washing with ethanol and DI water at least three times to make sure the supernatant fluid became colorless. The collected solid was dried at $60{ }^{\circ} \mathrm{C}$ overnight in a vacuum oven. Finally, the powder was heated at $350{ }^{\circ} \mathrm{C}$ for $3 \mathrm{~h}$ and then heated to $800^{\circ} \mathrm{C}\left(1^{\circ} \mathrm{C} \mathrm{min}^{-1}\right)$ and held at $800{ }^{\circ} \mathrm{C}$ for 5 hours in $\mathrm{N}_{2}$ gas flow. Different iron sources such as $\mathrm{FeCl}_{2} \bullet 4 \mathrm{H}_{2} \mathrm{O}$ (AR, General Reagent), $\mathrm{FeSO}_{4} \bullet 7 \mathrm{H}_{2} \mathrm{O}$ ( $\geqslant 99.0 \%$, General Reagent), $\mathrm{FeCl}_{3} \cdot 6 \mathrm{H}_{2} \mathrm{O}$ (AR, Hushi Reagent) and $\mathrm{Fe}(\mathrm{acac})_{3}$ (AR, Adamas Reagent) were used in the similar process. The amount of $\left(\mathrm{NH}_{4}\right)_{2} \mathrm{Fe}\left(\mathrm{SO}_{4}\right)_{2} \cdot 6 \mathrm{H}_{2} \mathrm{O}$ was varied and thus corresponding samples were marked as meso-Fe $\mathrm{x}_{\mathrm{x}} \mathrm{N}-\mathrm{C}$, $\mathrm{x}$ represents the concentration of iron precursor $\left(\mathrm{x}=10,1.0,0.1,0.05 \mathrm{mmol} \mathrm{L}^{-1}\right)$.

\section{Synthesis of meso-N-C catalysts}

The synthesis route of meso-N-C is similar to the meso-Fe-N-C, in the absence of iron precursor. Same to PDA/F127 composites and Fe/PDA/F127 composites.

\section{Characterization}

The Scanning Electron Microscopy (SEM) images were carried out on ZEISS Gemini SEM 300. The Transmission Electron Microscopy (TEM) images and EDS mapping were obtained on JEOL JEM F200 at $200 \mathrm{kV}$. Scanning Transmission Electron Microscopy (STEM) and AberrationCorrected Atomic-Resolution High-Angle Annular Dark-Field Scanning Transmission Electron Microscopy (AC HAADF-STEM) were carried out on a JEOL NEOARM at $200 \mathrm{kV}$. JEOL 1400 Flash with $120 \mathrm{kV}$ was used for regular TEM images. Fourier Transform Infrared spectra (FTIR) were measured on ThermoElectron Nicolet iS10 in the transmission mode with the wavelength range of $400 \sim 4000 \mathrm{~cm}^{-1}$. UV-visible spectrophotometry (UV-vis) absorption spectrum of the solution was obtained on Unico UV-2600 from $1100 \mathrm{~nm}$ to $191 \mathrm{~nm}$. Powder X-Ray Diffraction (XRD) patterns were recorded on Bruker D8 ADVANCE A25X X-ray diffractometer by using $\mathrm{Cu} \mathrm{Ka}(\lambda=1.54 \AA)$ radiation in the $2 \theta$ range of $10 \sim 80^{\circ}$ with the scan rate of $10^{\circ} \mathrm{min}$. Raman spectra were conducted on a Horiba Scientific LabRAM Raman NSOM with an excitation wavelength of $633 \mathrm{~nm}$ in a range of $800 \sim 2000 \mathrm{~cm}^{-1}$. N2 adsorption/desorption isotherms were collected on a Micromeritics ASAP2460 equipment at $77 \mathrm{~K}$. Before test, the samples were degassed at $180{ }^{\circ} \mathrm{C}$ for $10 \mathrm{~h}$ under vacuum. The specific surface area and pore size distribution were obtained by Brunauer-Emmett-Teller (BET) method and Barrett-Joyner-Halenda (BJH) model for mesopores and Density Functional Theory (DFT) model for micropores, respectively. X-ray Photoelectron Spectroscopy (XPS) analysis was implemented on Thermo Fisher Escalab 250Xi by using a monochromated Al K a X-ray source to

characterize the elementary composition and chemical valence states. Inductively Coupled Plasma Optical Emission Spectrometry (ICP-OES) data were acquired on Agilent ICP-OES730. Elemental Analysis (EA) was conducted on a Vario EL cube analysis system.

\section{Electrochemical Measurement}


RDE tests: Oxygen reduction reaction (ORR) test was conducted on a $\mathrm{CHI}$ 660E Electrochemical Workstation (CH Instruments) equipped with a modulated speed rotator (Pine instruments) with a glassy carbon disk $(\Phi=5 \mathrm{~mm}) . \mathrm{Hg} / \mathrm{HgO}(1.0 \mathrm{M} \mathrm{KOH})$ and the graphite rod were served as the reference electrode and counter electrode, respectively. To prepare a working electrode, $4.0 \mathrm{mg}$ catalyst powder was dispersed in a $1.0 \mathrm{~mL}$ solution containing $990 \mu \mathrm{L}$ isopropanol and $10 \mu \mathrm{L}$ Nafion solution $(0.5 \mathrm{wt} \%)$. Then, the catalyst ink was deposited onto the glassy carbon electrode and dried naturally at room temperature. Before the electrochemical measurements, the electrolyte was bubbling by Ar gas for 30 minutes to purge oxygen. All the potentials reported in this work were calibrated and referred to vs. reversible hydrogen electrode (RHE). The ORR performance of catalysts was evaluated in $\mathrm{O}_{2}$-saturated $0.1 \mathrm{M} \mathrm{KOH}$ electrolyte via linear sweep voltamperometry (LSV) in the range of $0.2 \sim 1.0 \mathrm{~V}(v s . \mathrm{RHE})$ at $1600 \mathrm{rpm}$ with a scan rate of $10 \mathrm{mV} \mathrm{s}^{-1}$. The accelerated degradation test was conducted under cycling between 0.6 and $1.0 \mathrm{~V}$ (vs. RHE) in $\mathrm{O}_{2}$-saturated $0.1 \mathrm{M} \mathrm{KOH}$. The amperometric i-t and chronoamperometry (CA) tests, were also carried out to evaluate the stability of catalysts.

Electron transfer number $(\mathbf{n})$ calculation: the electron transfer number $(\mathrm{n})$ was calculated by the Koutechy-Levich equation:

$$
\begin{gathered}
\frac{1}{j}=\frac{1}{j_{l}}+\frac{1}{j_{k}}=\frac{1}{B \omega^{\frac{1}{2}}}+\frac{1}{j_{k}} \\
B=0.62 n F C_{0} D_{0}^{\frac{2}{3}} v^{-\frac{1}{6}} \\
j_{k}=\frac{j_{l} \cdot j}{j_{l}-j}
\end{gathered}
$$

Where $j$ is the measured current density, $j_{k}$ and $j_{l}$ are the kinetic and limiting current density, $\omega$ is the angular velocity of the disk, $\mathrm{n}$ is the overall number of electron transferred in oxygen reduction, $\mathrm{F}$ is the Faraday constant $\left(96485 \mathrm{C} \mathrm{mol}^{-1}\right), \mathrm{C}_{0}$ is the bulk concentration of $\mathrm{O}_{2}\left(1.2 \times 10^{-6} \mathrm{~mol} \mathrm{~cm}^{-}\right.$ $\left.{ }^{3}\right)$, $\mathrm{D}_{0}$ is the diffusion coefficient of $\mathrm{O}_{2}\left(1.9 \times 10^{-5} \mathrm{~cm}^{2} \mathrm{~s}^{-1}\right), v$ is the kinematic viscosity of the electrolyte $\left(0.01 \mathrm{~cm}^{2} \mathrm{~s}^{-1}\right)$ and $\mathrm{k}$ is the electron transfer rate constant.

MEA tests: To prepare the catalyst ink, catalyst powder and anion exchange resin solution (5 wt\% Alkymer ${ }^{\circledR}$ I-250, EVE Institute of New Energy Technology) were mixed with isopropanol. Then, the catalyst ink was deposited onto the gas diffusion layer at $80^{\circ} \mathrm{C}$. Later, the coated electrode was put into $1.0 \mathrm{M} \mathrm{NaOH}$ at $60^{\circ} \mathrm{C}$ for $24 \mathrm{~h}$ to obtained $\mathrm{OH}^{-}$-type electrode via ion exchange. The alkaline anion exchange membrane (Alkymer ${ }^{\circledR} \mathrm{W}-25$, thickness: $25 \pm 2 \mu \mathrm{m}$, EVE Institute of New Energy Technology) was pretreated at the same condition to obtain the OH-type membrane. The 60 wt\% commercial PtRu/C (Johnson-Matthey In. UK) catalyst was used as anode catalyst, the mass loading of anode catalyst is $0.4 \mathrm{mg} \mathrm{cm}^{-2}$ with active area of $5 \mathrm{~cm}^{2}$, and the catalyst loading of meso-Fe-N-C is $4.0 \mathrm{mg} \mathrm{cm}^{-2}$ with active area of $1 \mathrm{~cm}^{2}$. The flow rate of $\mathrm{H}_{2}$ and $\mathrm{O}_{2}$ are 400 and 500 sccm, respectively. All the gases were $100 \%$ humidified at $80^{\circ} \mathrm{C}$, and the absolute pressures of $\mathrm{H}_{2}$ and $\mathrm{O}_{2}$ were the same and set at 2.0 bar.

TOF calculation: TOF is the turnover frequency in electrons per site per second, which presents the activity of the catalyst site. The value of the TOF is usually estimated on the basis of the equation at a given potential (based on the assumption that all Fe atoms are participating the reaction):

$$
\operatorname{TOF}\left[e \cdot \operatorname{site}^{-1} \cdot s^{-1}\right]=\frac{j_{k} \cdot M_{F e}}{m_{0} \cdot w_{F e} \cdot F}
$$


Where $\mathrm{j}_{\mathrm{k}}$ is the kinetic current, $\mathrm{m}_{\mathrm{0}}$ is the mass loading of catalysts on glassy carbon electrode surface, $\mathrm{w}_{\mathrm{Fe}}$ is the Fe content in the catalysts, $\mathrm{M}_{\mathrm{Fe}}$ is the atomic weight of $\mathrm{Fe}\left(55.845 \mathrm{~g} \mathrm{~mol}^{-1}\right), \mathrm{F}$ is the Faraday constant.

Site density (SD) calculation: Quantitative characterization of SD is according to the reported an in-situ electrochemical method in the literature. ${ }^{3-}$

${ }^{6}$ The catalysts were cycled in $0.5 \mathrm{M}$ acetate buffer before, during and after the $\mathrm{NO}_{2}{ }^{-}$absorption. The excess in cathodic charge ( $\mathrm{Q}_{s t r i p}$ ), calculated by comparing CV curves between -0.3 to $0.4 \mathrm{~V}$ ( vs. RHE) in $\mathrm{N}_{2}$ before and after poisoning, was associated with the stripping of nitrite anions. $\mathrm{Q}_{s t r i p}(\mathrm{C})$ was proportional to the $\mathrm{SD}\left(\mathrm{mol} \cdot \mathrm{g}^{-1}\right)$ :

$$
\begin{gathered}
Q_{\text {strip }}(C)=\frac{S_{\text {Area }} \cdot S_{G C E}}{\text { ScanRate }} \\
S D\left(\mathrm{~mol} \cdot \mathrm{g}^{-1}\right)=\frac{Q_{\text {strip }}(C)}{n \cdot F \cdot m_{0}}
\end{gathered}
$$

Where $\mathrm{S}_{\mathrm{Area}}\left(\mathrm{mA} \cdot \mathrm{cm}^{-2} \cdot \mathrm{V}\right)$ is the difference of geometric area of $\mathrm{CV}$ before and after poisoning, $\mathrm{S}_{\mathrm{GCE}}\left(\mathrm{cm}^{2}\right)$ is the geometric area of glass carbon electrode, the ScanRate is $10 \mathrm{mV} \mathrm{s}^{-1}, \mathrm{n}=5$ is the number of electrons associated with the reduction of one nitrite per site.

Fe utilization (u\%) calculation: Basing on the SD and the mass concentration of Fe in the catalysts(quantified by ICP),

$$
u \%=\frac{S D \cdot m_{0}}{n_{F e}} \times 100 \%=\frac{S D \cdot m_{0}}{\frac{m_{0} \cdot w_{F e}}{M_{F e}}} \times 100 \%=\frac{S D \cdot M_{F e}}{w_{F e}} \times 100 \%
$$

Where $\mathrm{n}_{\mathrm{Fe}}(\mathrm{mol})$ is the mol amount of Fe in the catalysts. 

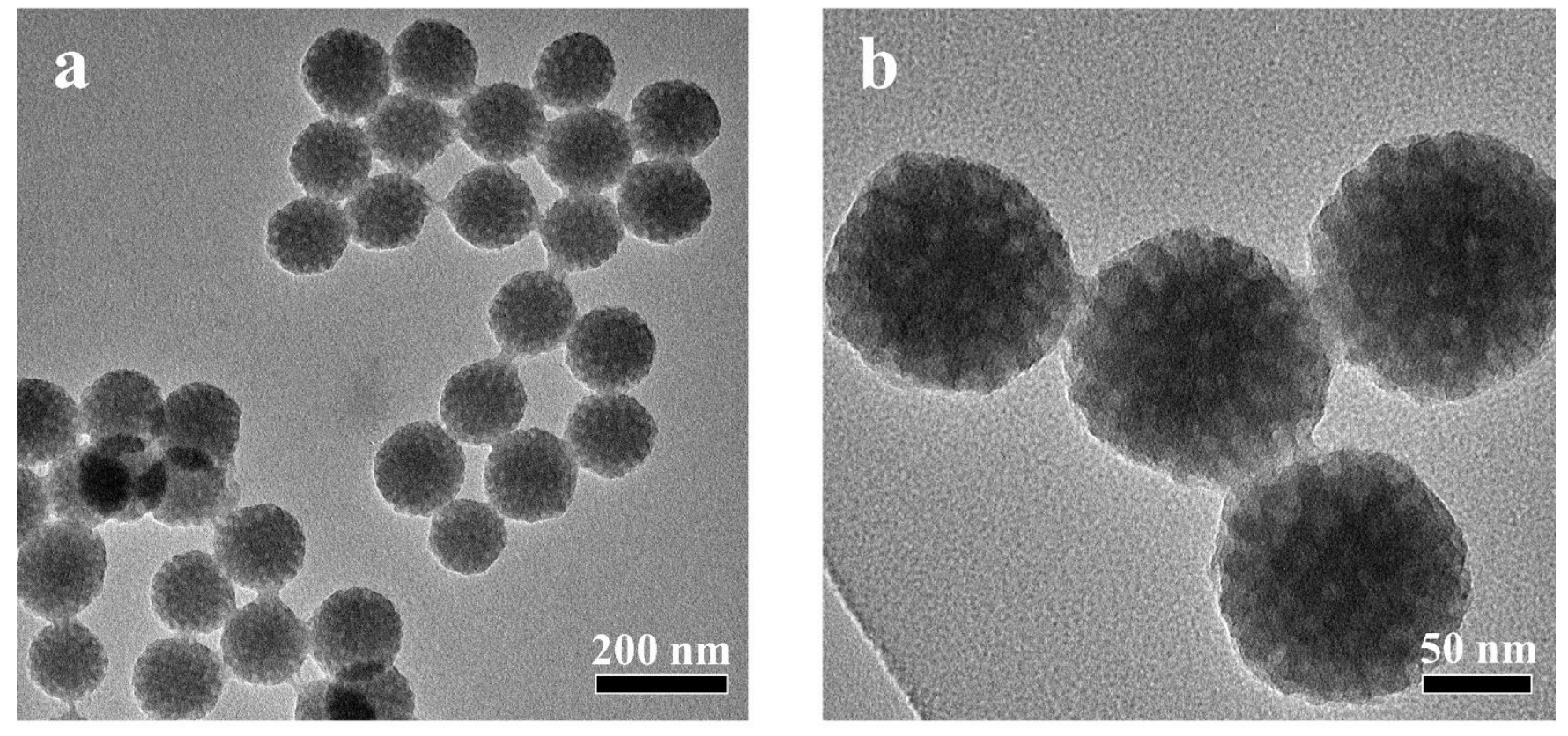

Figure S1. TEM images of Fe/PDA/F127 composites. 

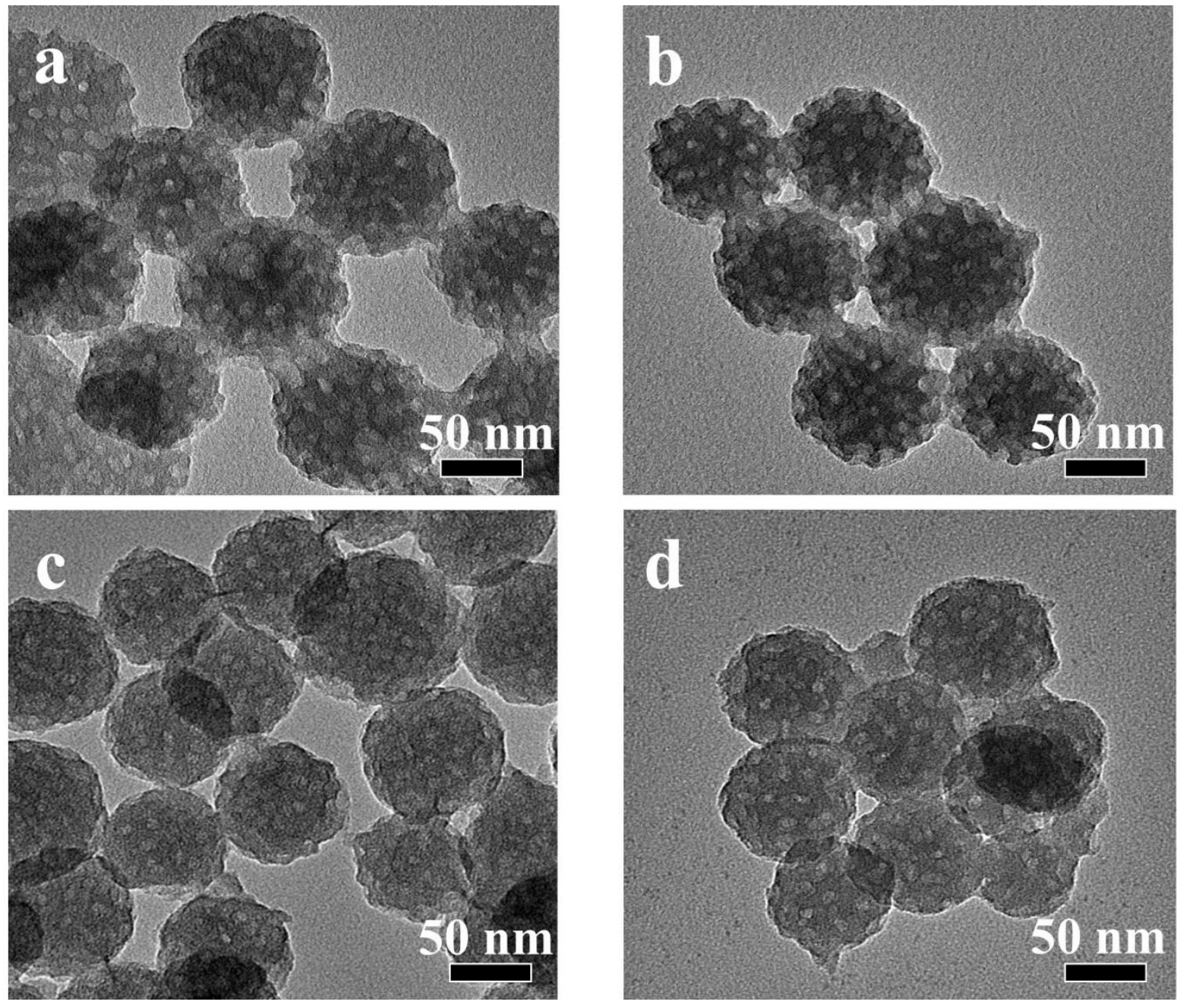

Figure S2. TEM images of (a, b) PDA/F127 composites, and (c, d) meso-N-C. 


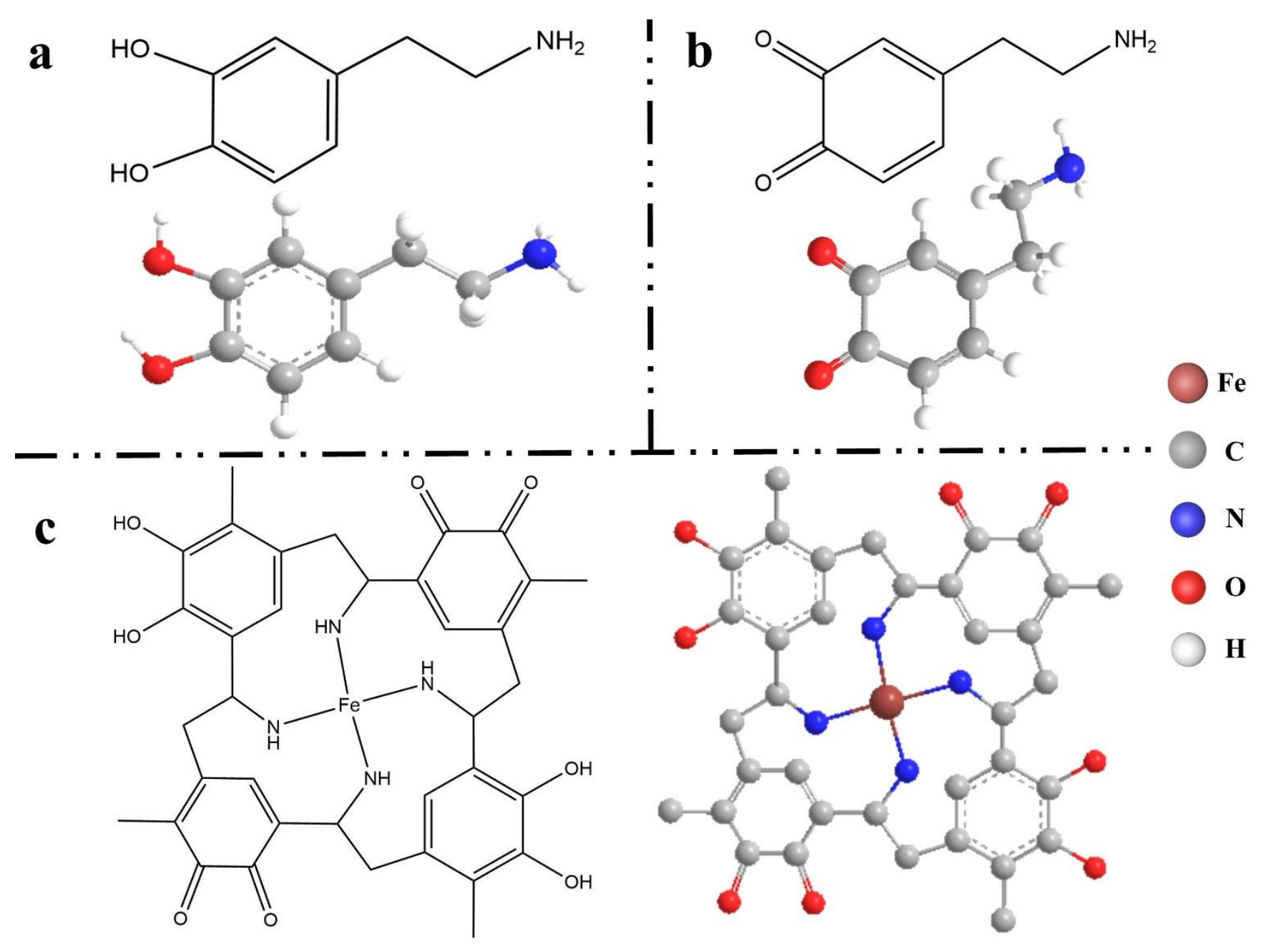

Figure S3. Structure of (a) Dopamine, (b) Quinone, (c) Polydopamine bonding with Fe. 

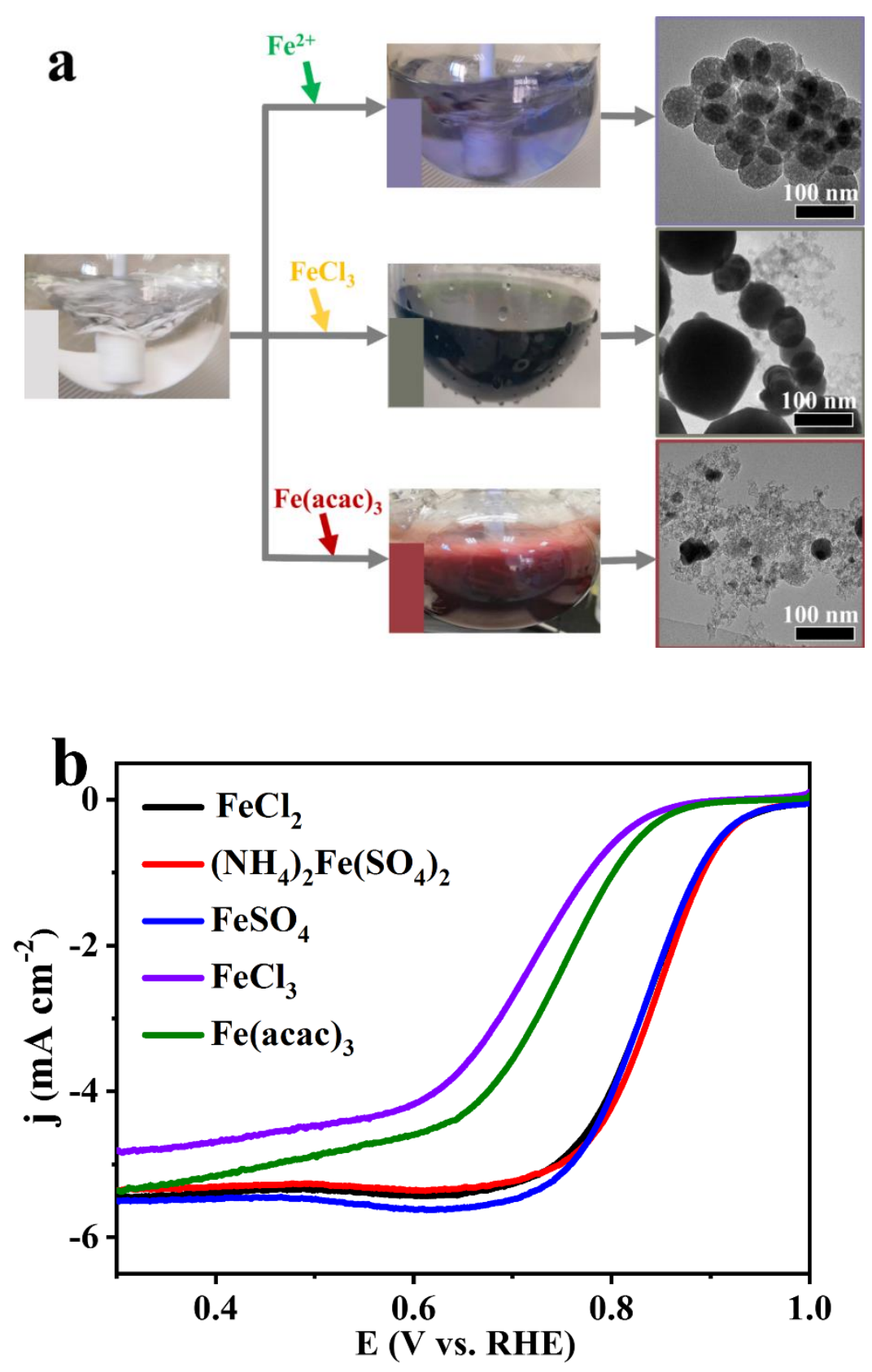

Figure S4. (a) Photos of reactions and corresponding TEM images of products. (b) LSV curves of meso-Fe-N-C with different iron precursors in an $\mathrm{O}_{2}$-saturated $0.1 \mathrm{M} \mathrm{KOH}$, loading: $0.4 \mathrm{mg} \mathrm{cm}^{-2}$. Various Fe precursors have been investigated for the synthesis of atomic Fe decorated mesoporous carbon nanospheres. Three kinds of meso-Fe-N-C with different $\mathrm{Fe}^{2+}$ precursors show little difference in morphology and ORR performance. When $\mathrm{FeCl}_{3}$ in the place of $\left(\mathrm{NH}_{4}\right)_{2} \mathrm{Fe}\left(\mathrm{SO}_{4}\right)_{2}$ is employed, the yellow $\mathrm{Fe}^{3+}$ aqueous solution immediately turns into dark green, indicating that Fe(III) ions are reduced to $\mathrm{Fe}$ (II) and DA might be oxidized to quinone derivatives. The weak chelate ability of quinone derivatives leads to the separate domains of $\mathrm{Fe}$ ion and dopamine derivatives, thus nonuniform large iron particles $(200 \sim 500 \mathrm{~nm})$ appear after high-temperature thermal treatment. As for $\mathrm{Fe}(\mathrm{acac})_{3}$, the hydrolysis and release of $\mathrm{Fe}(\mathrm{III})$ is much slower than inorganic salts, which might account for the formation of aggregated iron particle. 

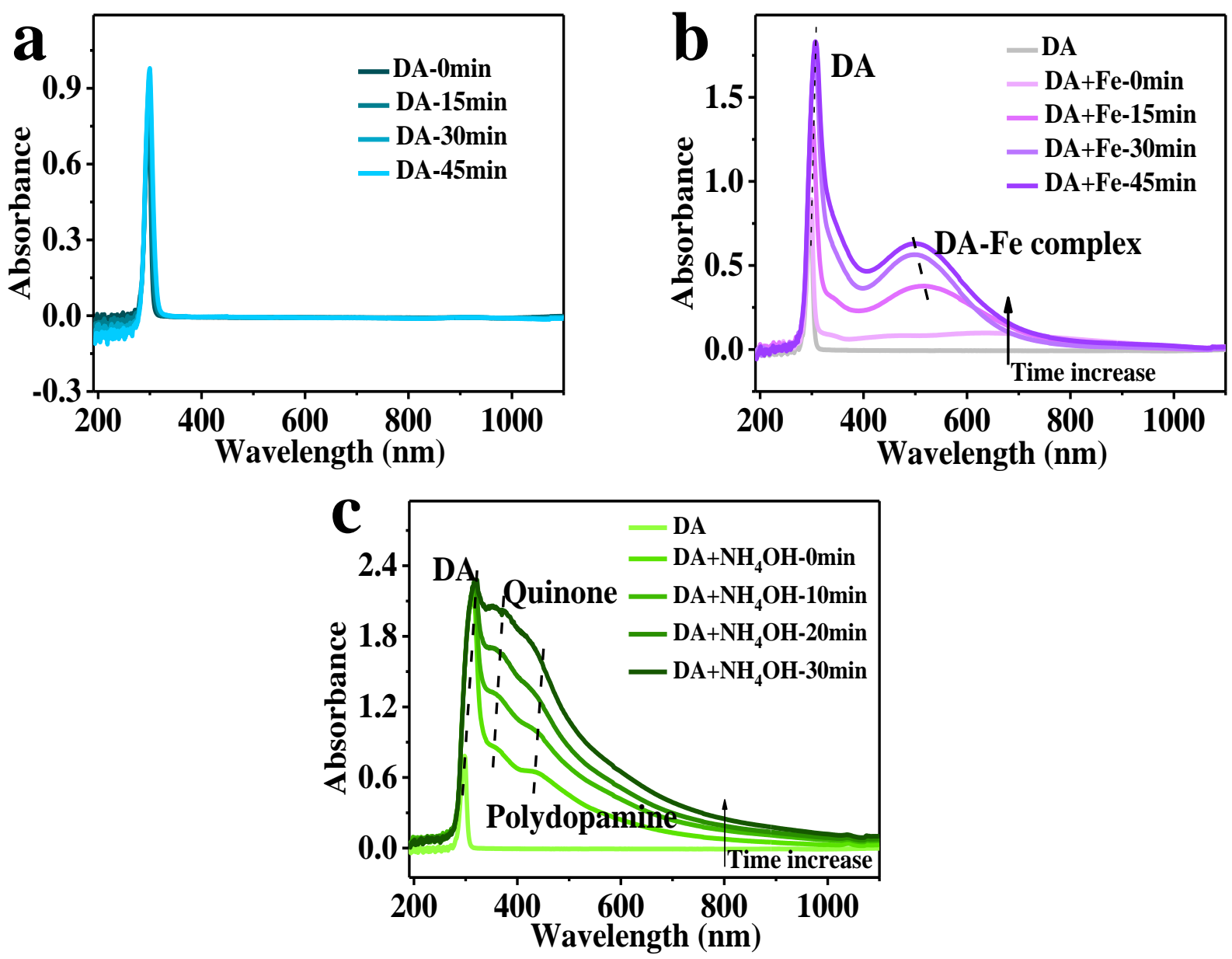

Figure S5. UV-vis spectra of (a) DA; (b) DA and $\left(\mathrm{NH}_{4}\right)_{2} \mathrm{Fe}\left(\mathrm{SO}_{4}\right)_{2}$; (c) $\mathrm{DA}$ and $\mathrm{NH}_{4} \mathrm{OH}$ in ethonal/DI Water mixture at different reaction time. In the presence of dopamine, (a) only one peak at $\sim 300 \mathrm{~nm}$ was detected even at different reaction time, and this peak is recognized as the characteristic peak of dopamine. While adding the Fe precursor into reaction mixture, a wide peak around $500 \mathrm{~nm}$ appeared in (b), which is different from the peak position of dopamine polymerization caused by adding $\mathrm{NH}_{4} \mathrm{OH}$ as initiator. As the peaks at $320 \sim 350 \mathrm{~nm}$ and $430 \sim 450 \mathrm{~nm}$ could be attributed to quinone and polydopamine ${ }^{2}$, so the broad peak at $\sim 500 \mathrm{~nm}$ might belong to dopamine-iron(DA-Fe) complex. 


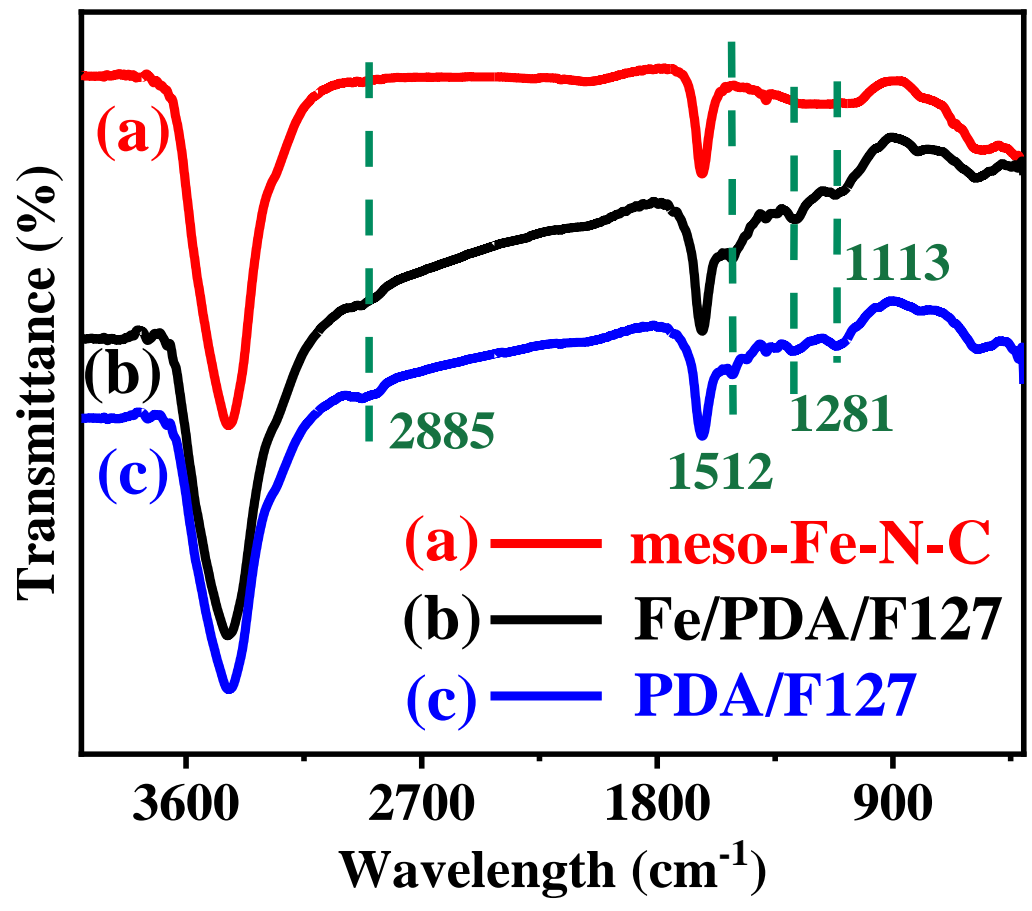

Figure S6. FTIR spectra of (a) meso-Fe-N-C, (b) Fe/PDA/F127 composites, and (c) PDA/F127 composites. Peaks at 1113, 1281,1512 and 2885 $\mathrm{cm}^{-1}$ are ascribed to the C-O-C stretch, $\mathrm{CH}_{2}$ twist, C-C stretch and $\mathrm{O}-\mathrm{H}$ stretch of $\mathrm{F} 127$, respectively. 

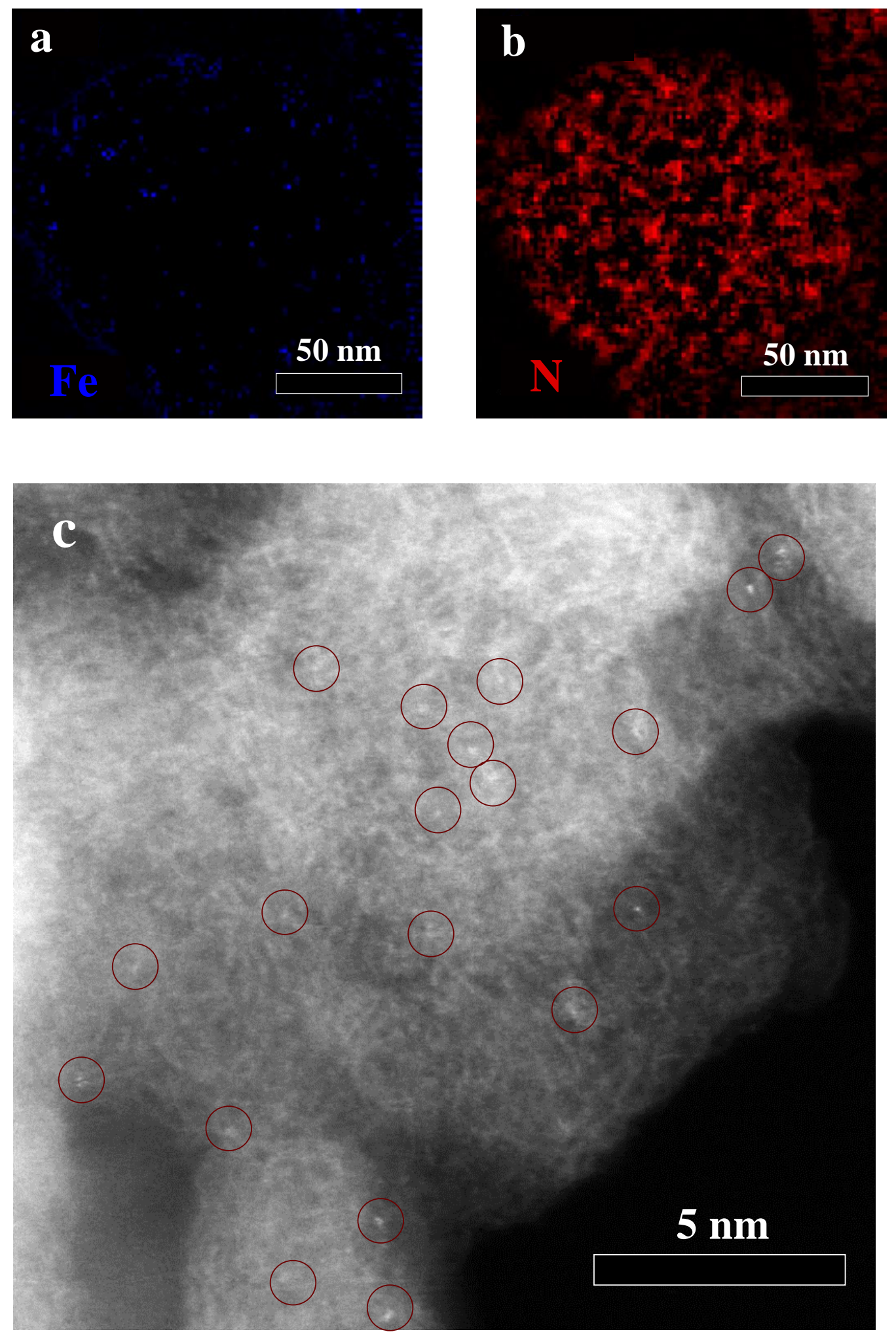

Figure S7. (a-b) corresponding EELS element mapping of Figure 1 g-h. (c) HAADF-STEM image of meso-Fe-N-C. 

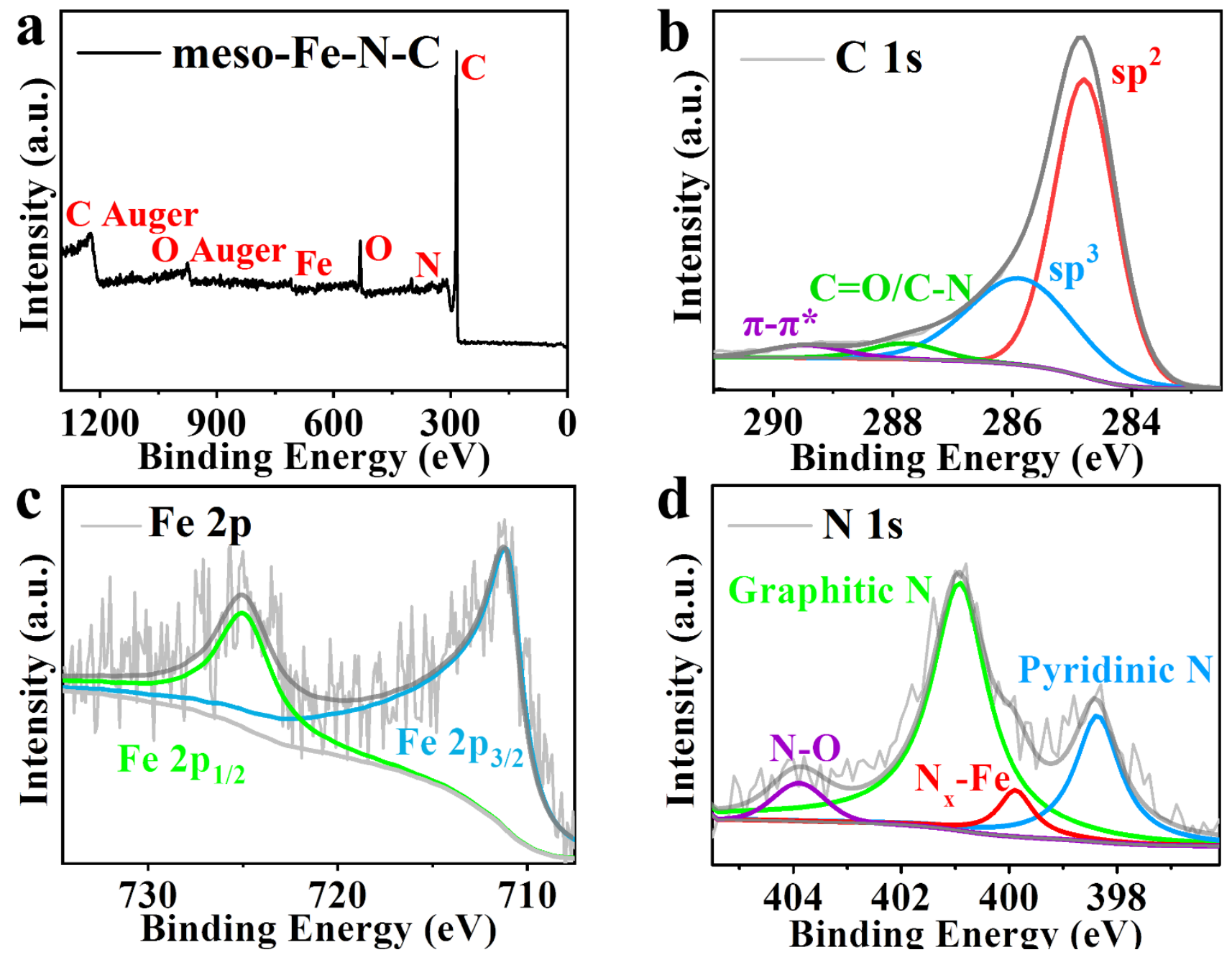

Figure S8. XPS spectra of meso-Fe-N-C. (a) the survey curves; (b) the C 1s spectrum; (c) the Fe 2p spectrum; (d) the N 1s spectrum. The full spectrum of meso-Fe-N-C confirms the presence of Fe, N, C and O (Figure S8a). The high-resolution C 1s spectrum (Figure S8b) can be divided into four characteristic peaks that corresponds to $\mathrm{sp}^{2}(284.8 \mathrm{eV}), \mathrm{sp}^{3}(285.9 \mathrm{eV}), \mathrm{C}=\mathrm{O} / \mathrm{C}-\mathrm{N}$ bonds $(287.8 \mathrm{eV})$ and shakeup $\pi-\pi^{*}$ satellite $(289.5 \mathrm{eV}) .^{7} \mathrm{The} \mathrm{high-}$ resolution spectrum of Fe $2 \mathrm{p}$ (Figure $\mathrm{S} 8 \mathrm{c}$ ) is deconvoluted into peaks at 711.3 and $724.9 \mathrm{eV}$, which are assigned to Fe $2 \mathrm{p}_{3 / 2}{ }^{8}$ and $\mathrm{Fe} 2 \mathrm{p}_{1 / 2},{ }^{9}$ respectively. The N 1s spectrum (Figure S8d) can be fitted by four components located at $398.3 \mathrm{eV}$ (Pyridinic N), ${ }^{10} 399.9 \mathrm{eV}\left(\mathrm{N}_{\mathrm{x}}-\mathrm{Fe}\right),{ }^{11-13} 401.0 \mathrm{eV}(\mathrm{Graphitic} \mathrm{N}){ }^{14}$, ${ }^{15}$ and $404.0 \mathrm{eV}$ (N-oxide) ${ }^{11}$ in which the presence of $\mathrm{N}_{\mathrm{x}}$-Fe is consistent with that of Fe $2 \mathrm{p}$ spectrum. Combining the XPS results with above TEM and ICP analysis, it indicates plenty of ORR active atomic Fe- $\mathrm{N}_{\mathrm{x}}$ sites $^{16,17}$ well dispersed in the hierarchical mesoporous carbon spheres. Based on the XPS results and the reported polymerization mechanism ${ }^{18-21}$ of polydopamine, the possible structure of Fe-N species are shown in Figure S3c. 

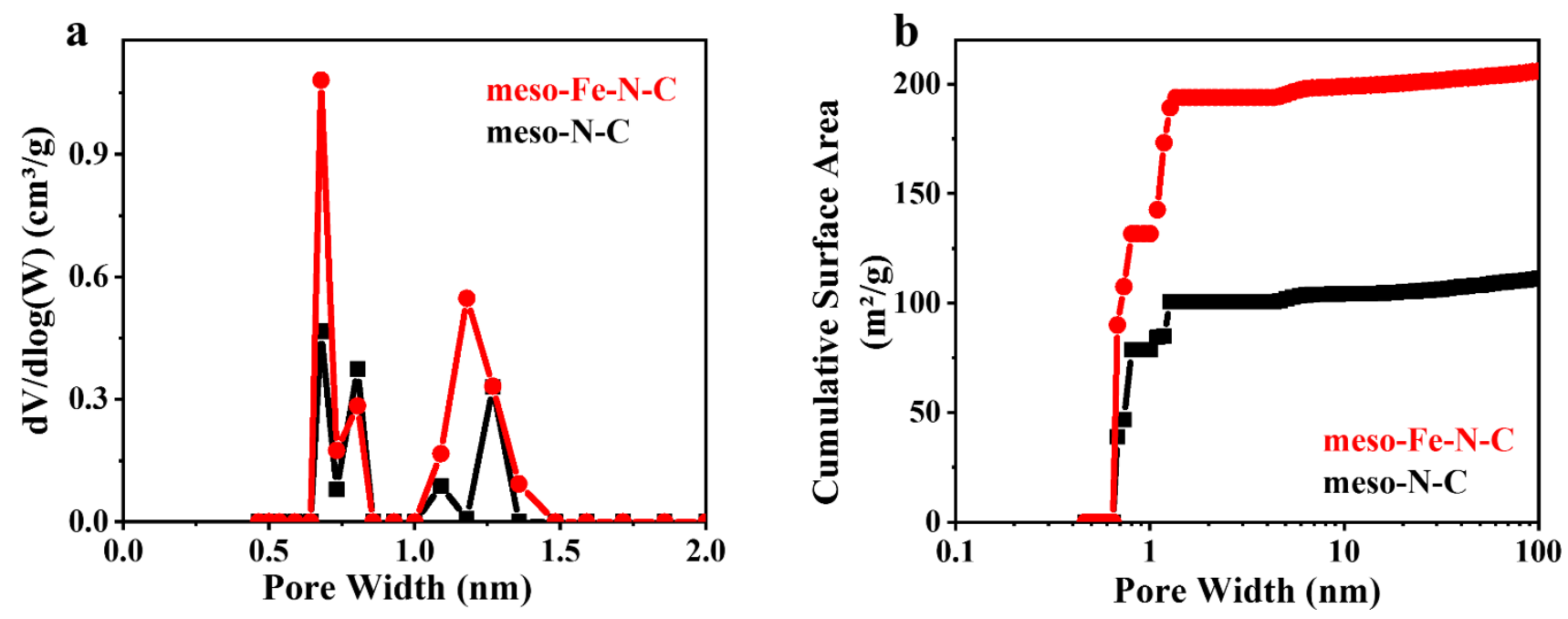

Figure S9. (a) Pore size distributions calculated by DFT model derived from the desorption branch, (b) cumulative surface area as function of pore size of meso-Fe-N-C and meso-N-C. 

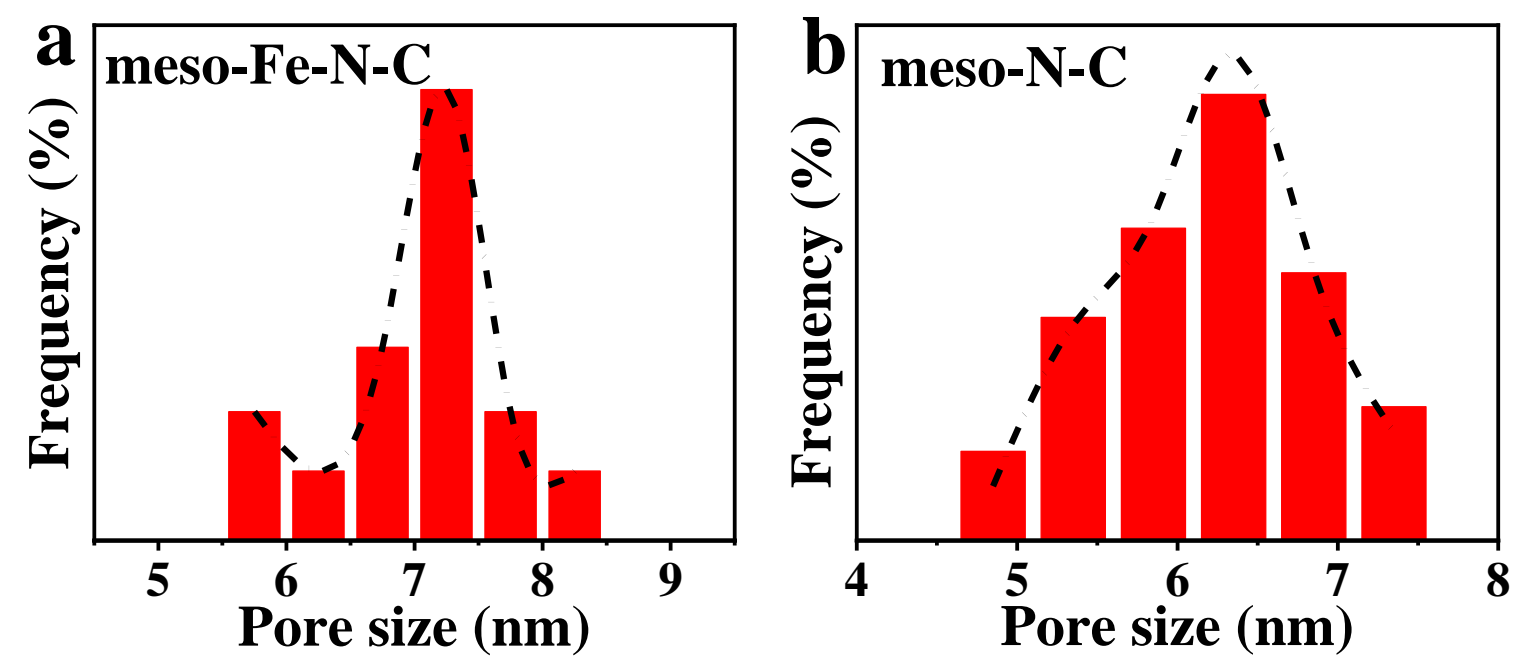

Figure S10. Histogram of pore size is counted by TEM images (a) meso-Fe-N-C, (b) meso-N-C. 

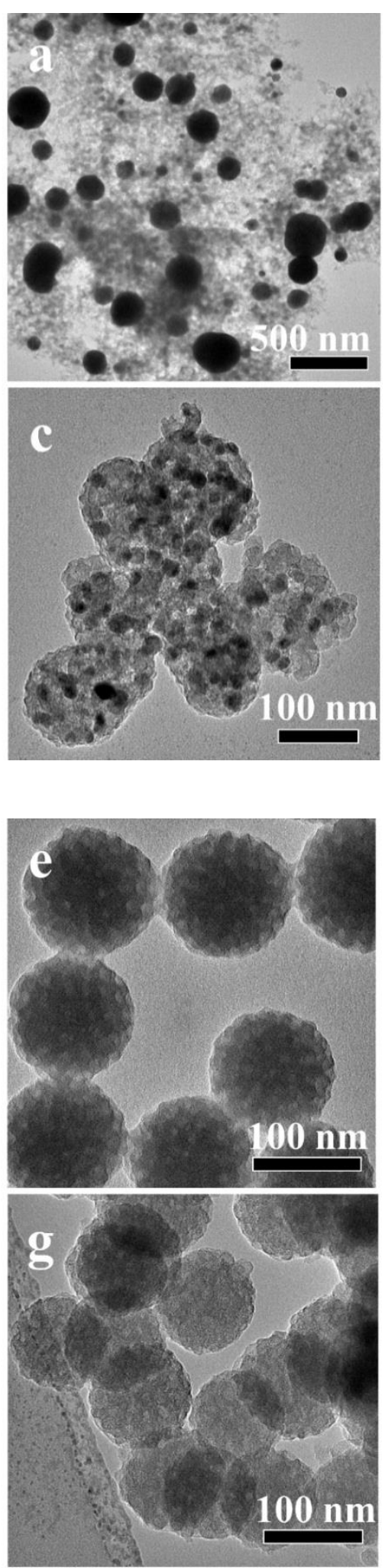
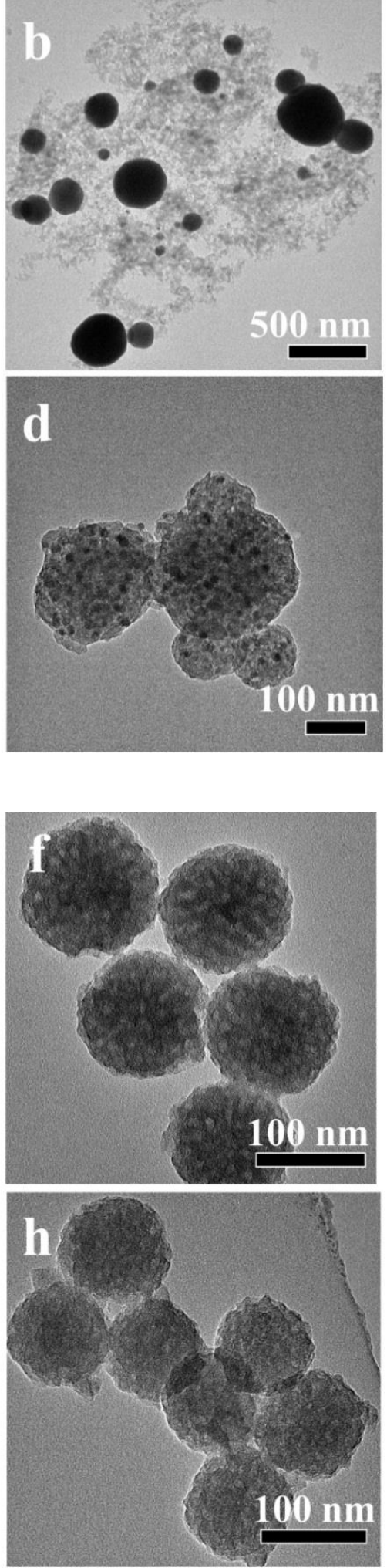

Figure S1 1. TEM images of meso-Fe $e_{x}-\mathrm{N}-\mathrm{C}$ with various Fe content: (a, b) meso-Fe $e_{10}-\mathrm{N}-\mathrm{C}$, (c, d) meso-Fe $1.0-\mathrm{N}-\mathrm{C}$, (e, f) meso-Fe-N-C, (g, h) meso$\mathrm{Fe}_{0.05}-\mathrm{N}-\mathrm{C}$. 

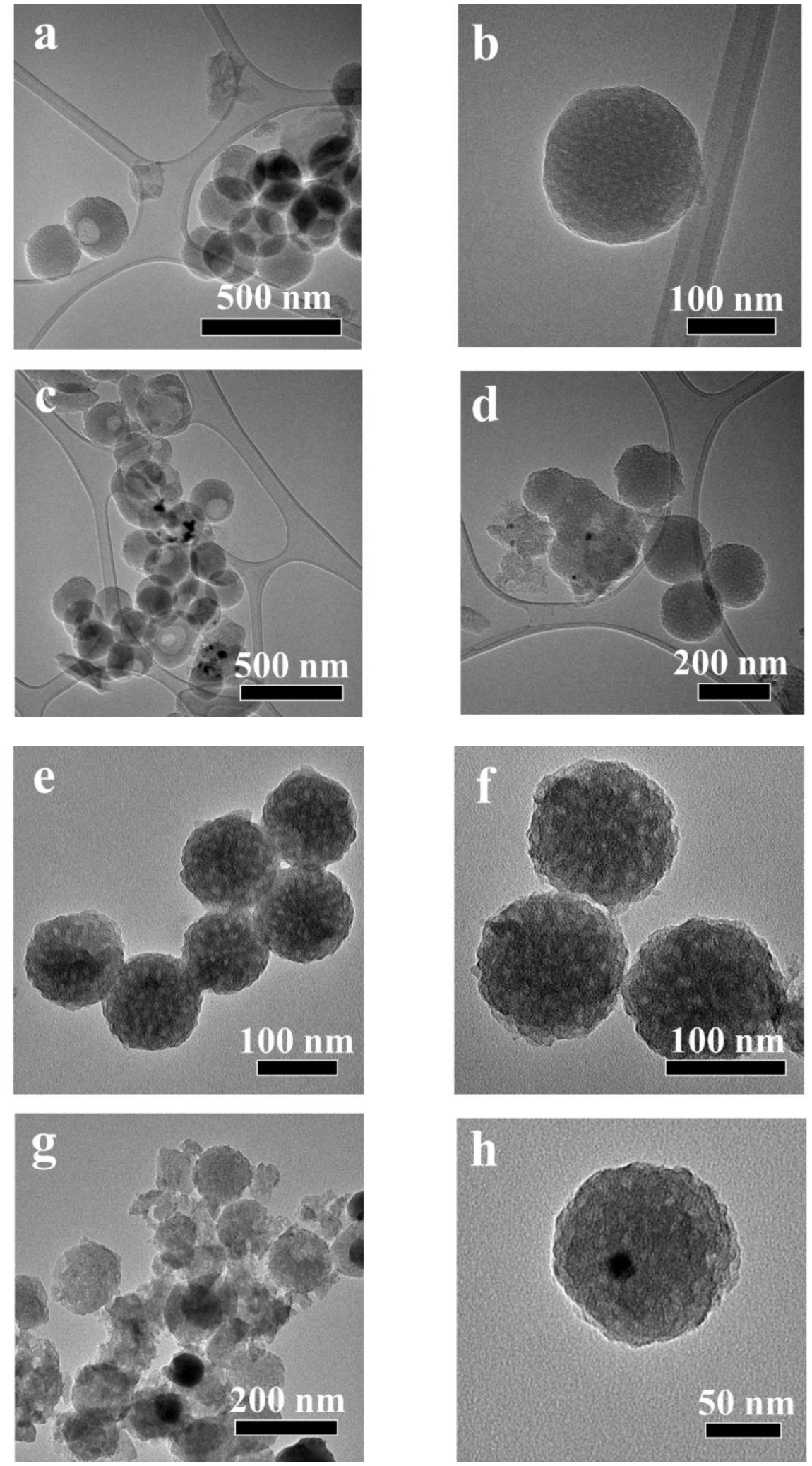

Figure S12. TEM images of meso-Fe-N-C pyrolyzed at (a, b) $700{ }^{\circ} \mathrm{C}, 5 \mathrm{~h} .(\mathrm{c}, \mathrm{d}) 900{ }^{\circ} \mathrm{C}, 5 \mathrm{~h}$; (e, f) $800{ }^{\circ} \mathrm{C}, 2 \mathrm{~h},(\mathrm{~g}, \mathrm{~h}) 800^{\circ} \mathrm{C}, 8 \mathrm{~h}$. 

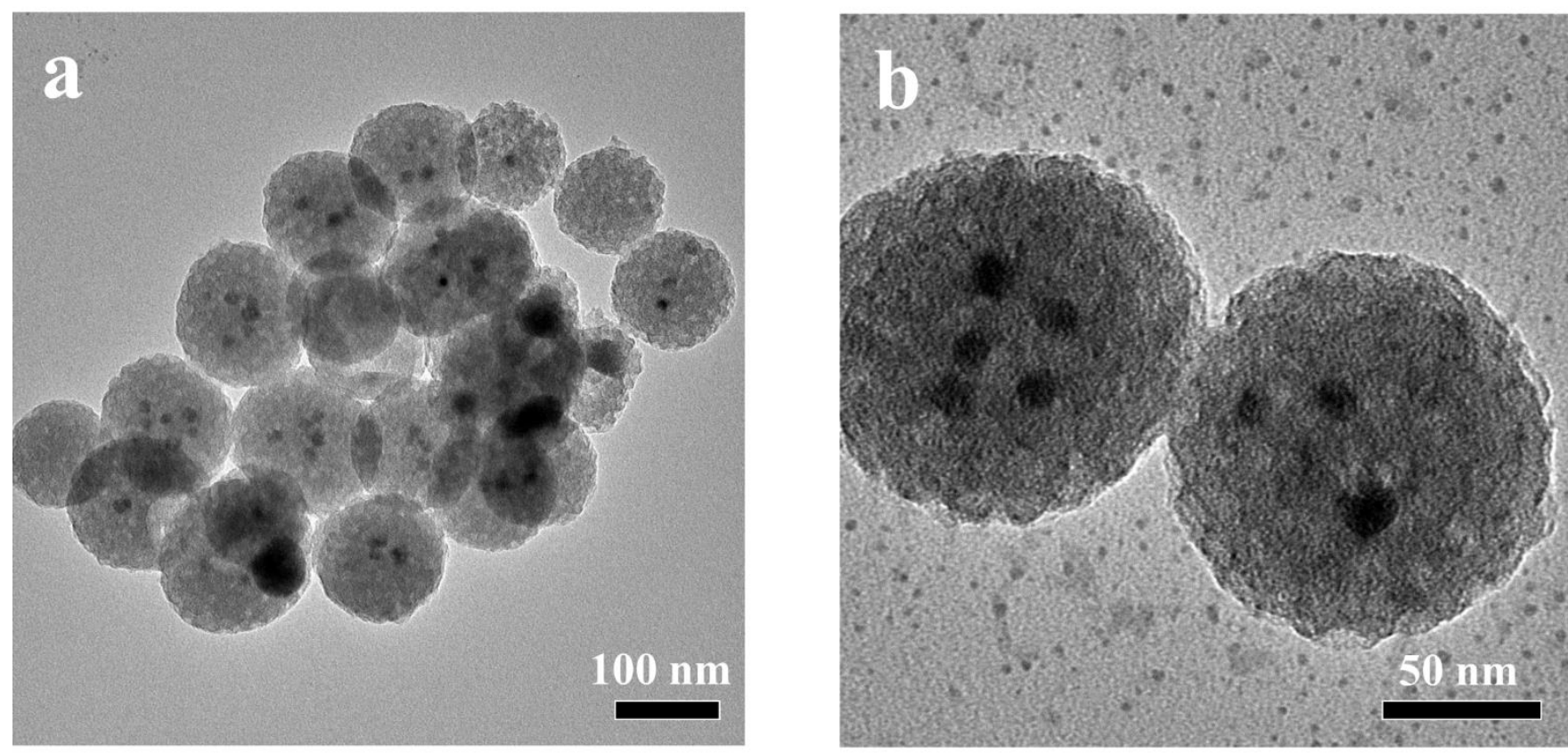

Figure S13. TEM images of meso-Fe-N-C- $\mathrm{H}_{2}$ nanospheres. 

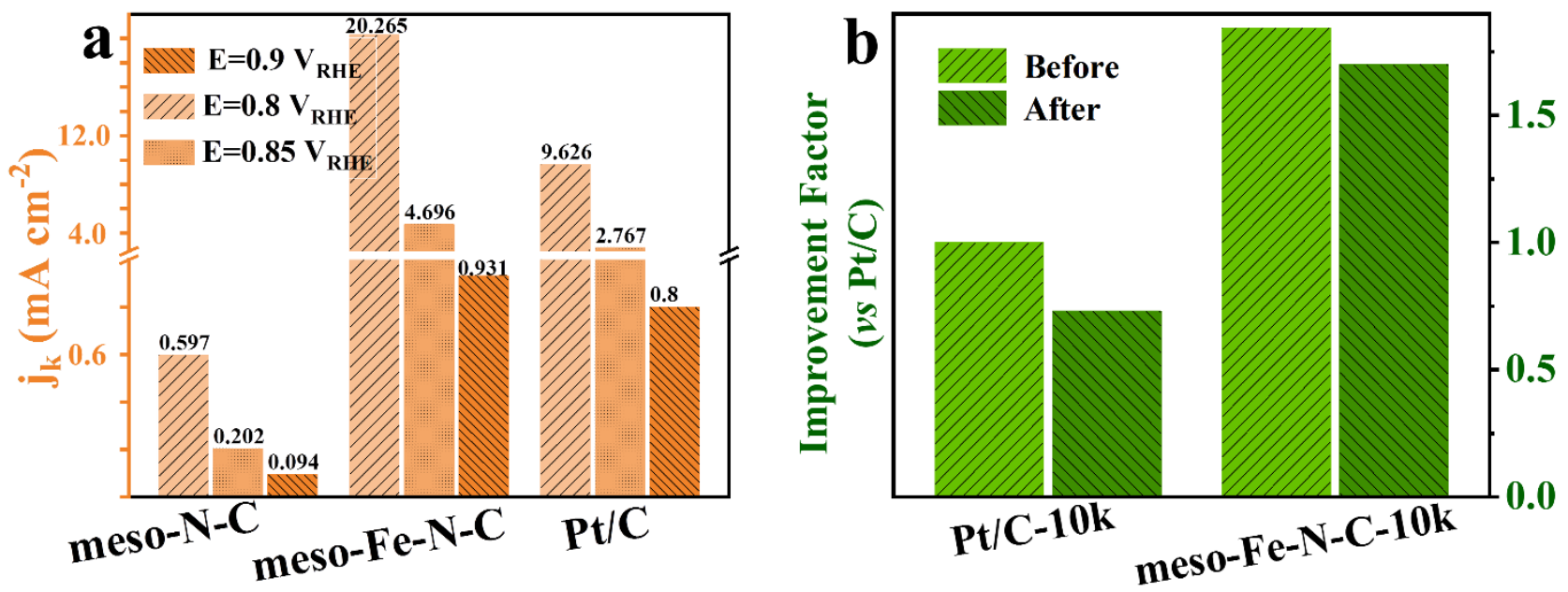

Figure S14. (a) Comparison of $j_{k}$ at different potential for meso-N-C, meso-Fe-N-C and $\mathrm{Pt} / \mathrm{C}$ in an $\mathrm{O}_{2}$-saturated $0.1 \mathrm{M} \mathrm{KOH}$ aqueous solution. (b) Improvement factor (vs. Pt/C) of $j_{k}$ before and after 10000 cycles. 

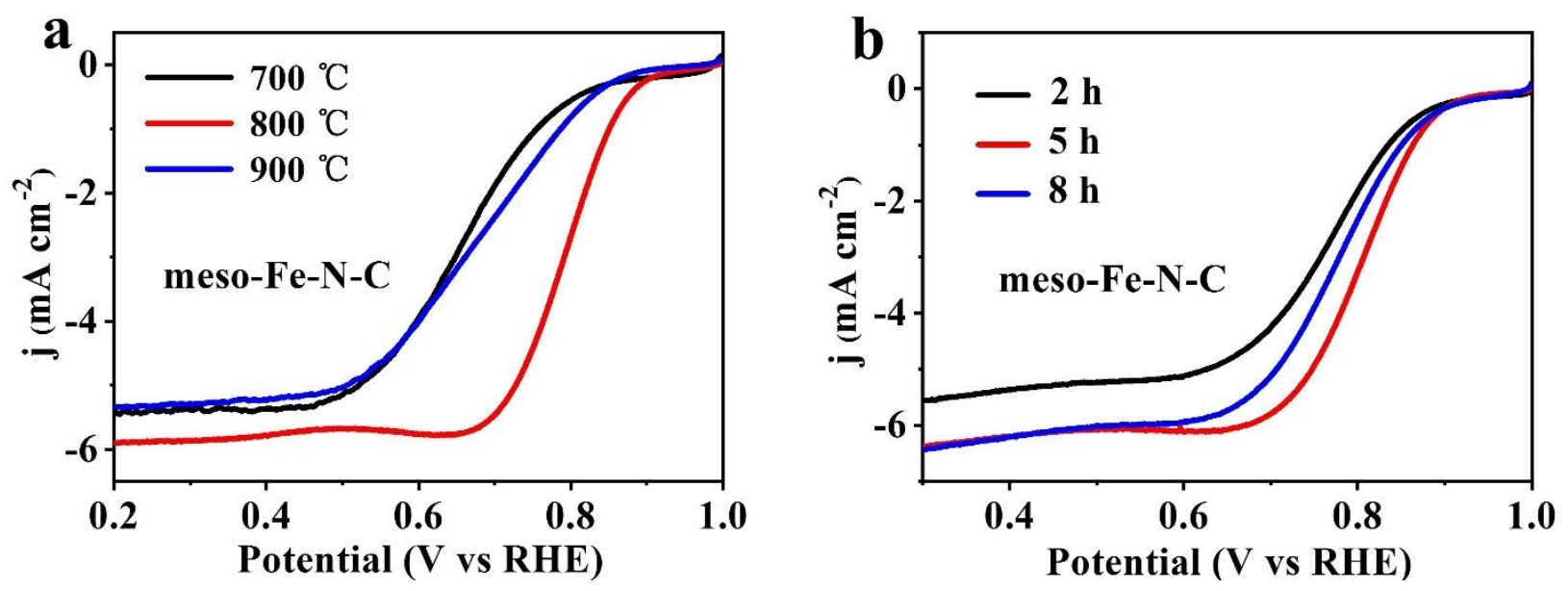

Figure S15. ORR perfomance of meso-Fe-N-C at (a) various pyrolysis temperatures, loading: $0.3 \mathrm{mg} \mathrm{cm}^{-2}$; (b) different pyrolysis times, loading: 0.3 $\mathrm{mg} \mathrm{cm}{ }^{-2} .700{ }^{\circ} \mathrm{C}, 5 \mathrm{~h}$ and $800{ }^{\circ} \mathrm{C}, 2 \mathrm{~h}$ maybe insufficient graphitization, from the TEM images of Figure $\mathrm{S} 11,900{ }^{\circ} \mathrm{C}, 5 \mathrm{~h}$ and $800{ }^{\circ} \mathrm{C}, 8 \mathrm{~h}$ led the agglomerated Fe-based particles, that's why the performance is not as good as $800^{\circ} \mathrm{C}, 5 \mathrm{~h}$ in $\mathrm{O}_{2}$-saturated $0.1 \mathrm{M} \mathrm{KOH}$. 


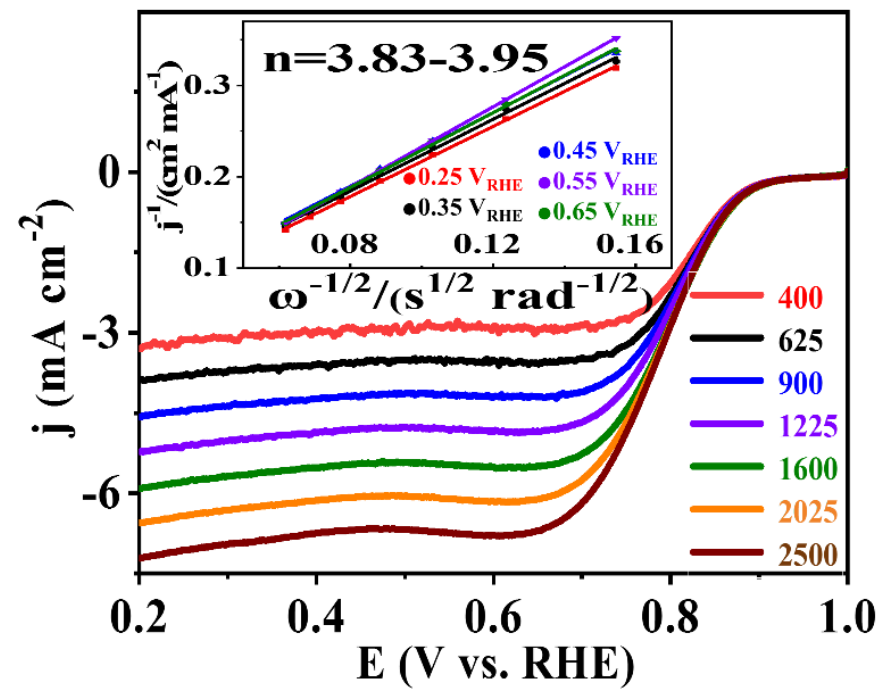

Figure S16. ORR curves of meso-Fe-N-C at different rotating rates in $\mathrm{O}_{2}$-saturated $0.1 \mathrm{M} \mathrm{KOH}$; inset: K-L plots and electron-transfer numbers, loading: $0.2 \mathrm{mg} \mathrm{cm}^{-2}$. 


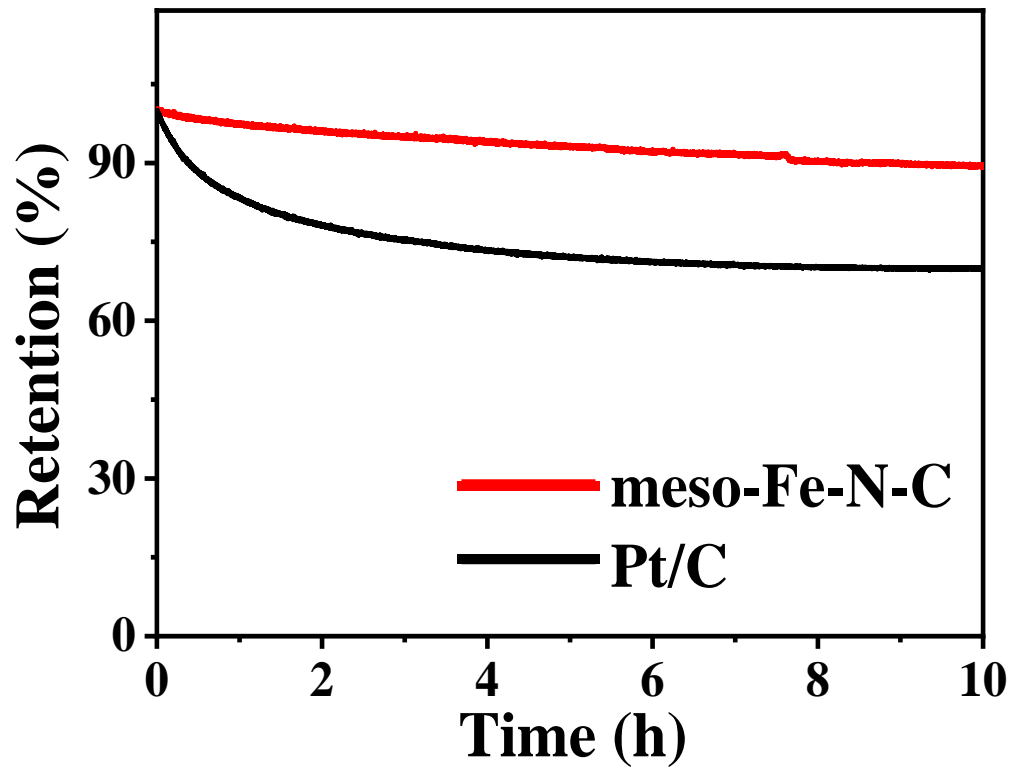

Figure S17. i-t curves of meso-Fe-N-C and Pt/C at a bias of $0.5 \mathrm{~V} v$ s. $\mathrm{RHE}$ in $\mathrm{O}_{2}$-saturated $0.1 \mathrm{M} \mathrm{KOH}$. 

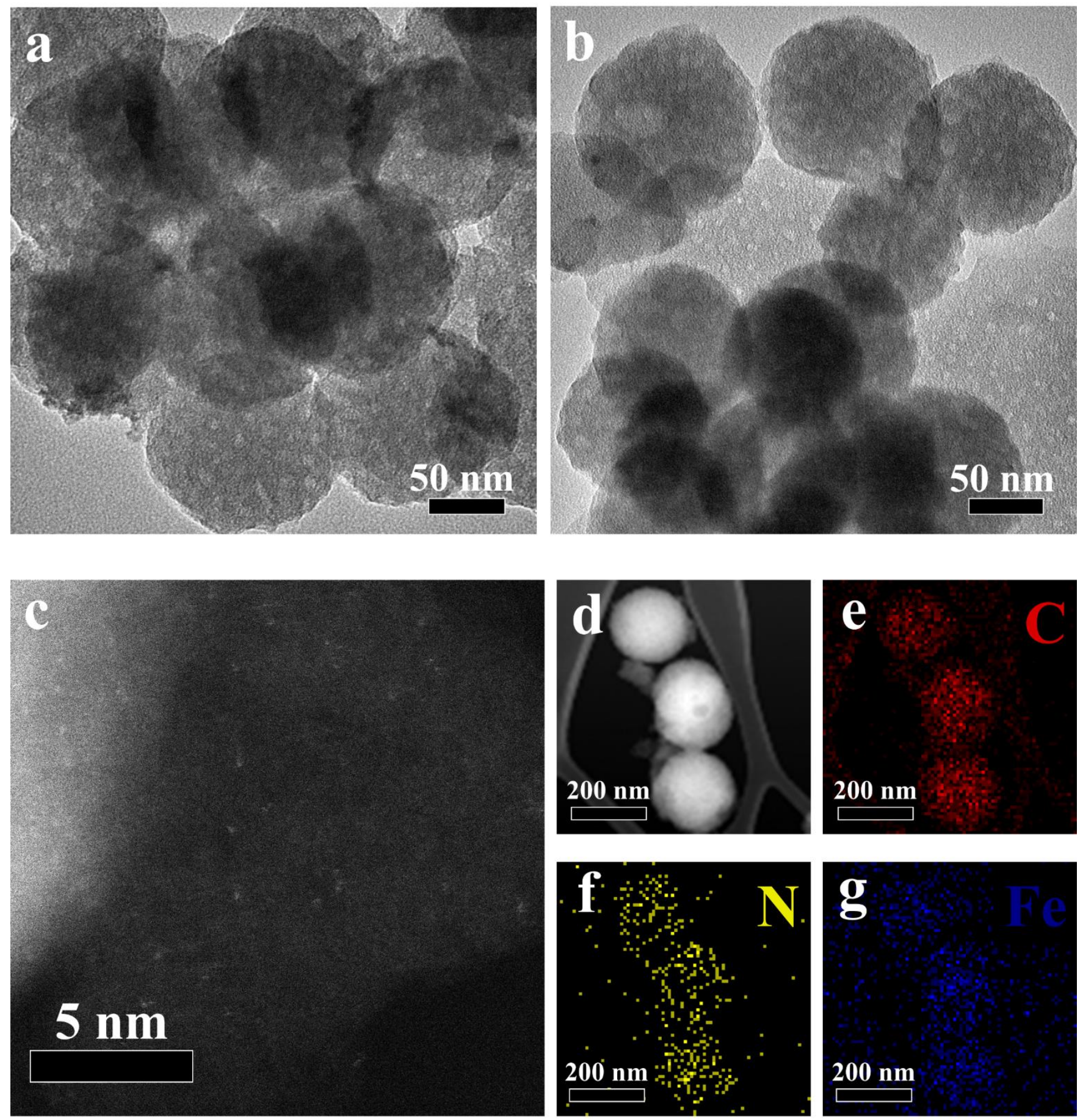

Figure S18. TEM images of meso-Fe-N-C after stability test: (a) 5000 cycles; (b) 10000 cycles. (c) HAADF-STEM images of meso-Fe-N-C, (d) STEM images and the corresponding (e-g) EDS element maps (C: red; N: yellow, Fe: blue) after 5000 cycles. 

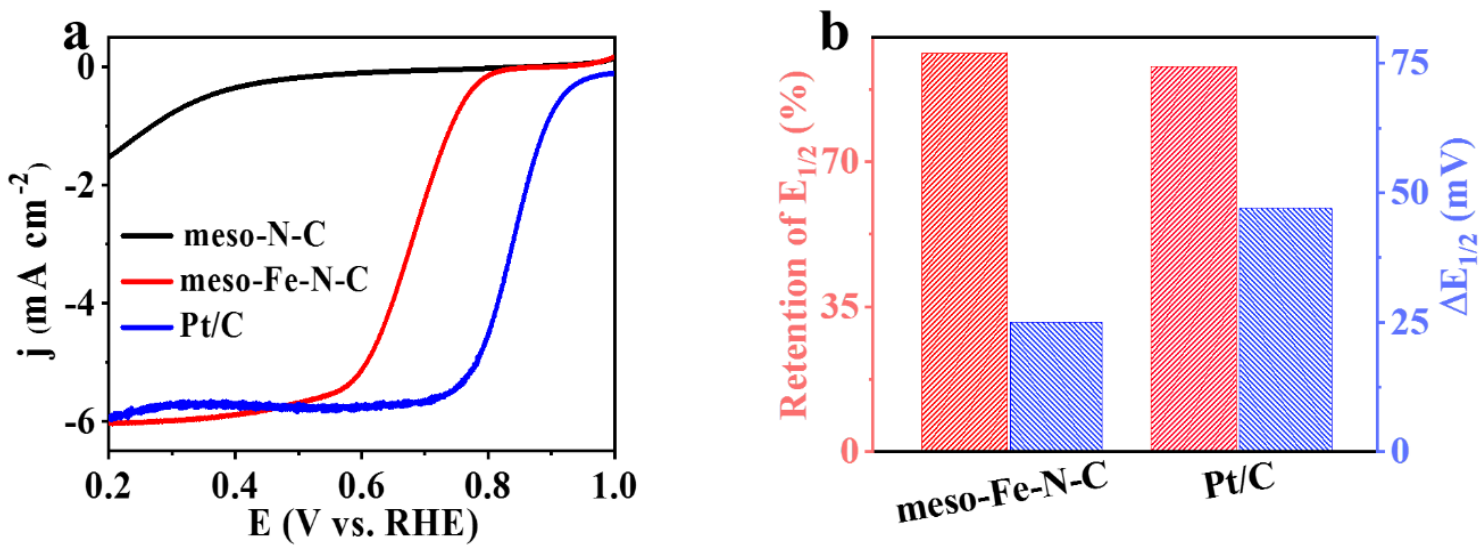

Figure S19. (a) ORR polarization curves for meso-N-C, meso-Fe-N-C and Pt/C, loading of meso-N-C and meso-Fe-N-C: $0.4 \mathrm{mg} \mathrm{cm}^{-2}$, loading of $\mathrm{Pt} / \mathrm{C}: 0.1 \mathrm{mg} \mathrm{cm}^{-2}$. (b) retention of $\mathrm{E}_{1 / 2}$ and $\Delta \mathrm{E}_{1 / 2}$ after 5000 cycles. 
a

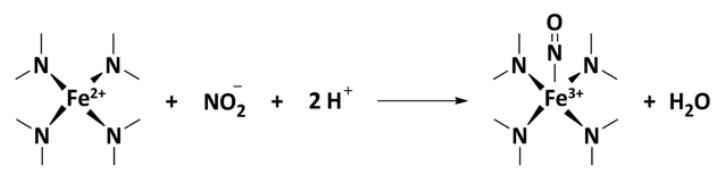

b

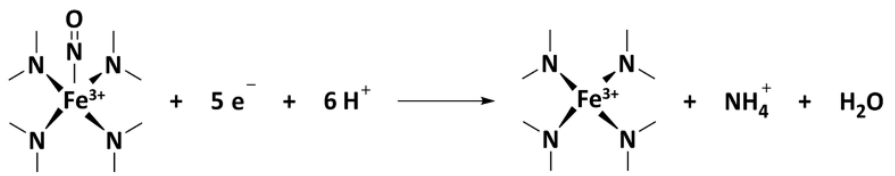

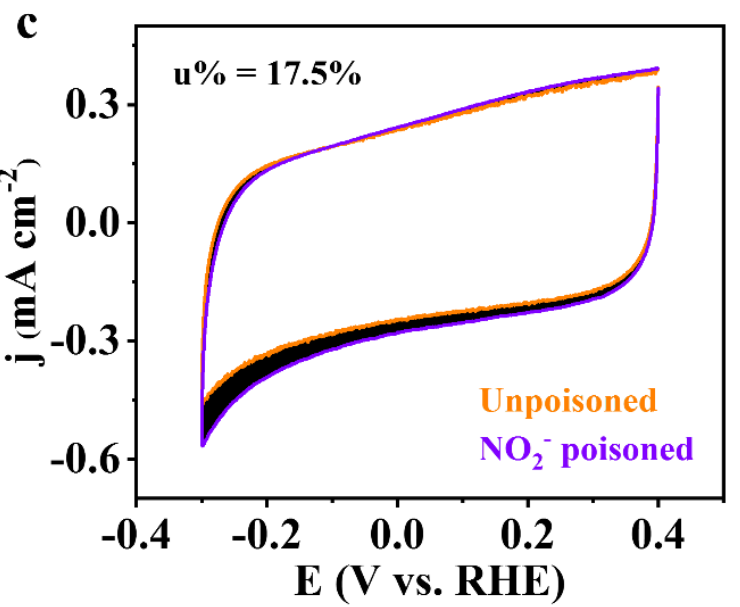

Figure S20. Scheme of (a) the nitrite ligand is transformed to a nitrosyl ligand upon cycling with a net reaction, (b) the stripping product is ammonia and therefore a transfer of 5 electrons per stripped molecule; (c) CV curves before and during nitrite adsorption in the nitrite reductive stripping region (The choice of baseline affects the accuracy of the peak). Note: due to the nature of atomic catalyst for the meso-Fe-N-C, the method may have a significant error, and therefore the result is not reliable. The Fe utilization estimated here is for reference only, which is neither conclusive nor necessarily accurate. Most likely, the Fe utilization is underestimated here or otherwise the TOF is substantially underestimated. Nevertheless, whichever is underestimated does not change the fact that meso-Fe-N-C has an outstanding overall electrocatalytic performance toward ORR. 
Table S1. Comparison of ORR performance for Fe-N-C-based catalysts in $0.1 \mathrm{M} \mathrm{KOH}$ solution.

\begin{tabular}{|c|c|c|c|c|c|}
\hline Catalysts & $\begin{array}{c}\text { Cat. } \\
\text { Loading } \\
\left.(\mathrm{mg} \mathrm{cm})^{-2}\right)\end{array}$ & $\begin{array}{c}\mathbf{E}_{1 / 2} \\
(\mathrm{~V} \text { vs. } \mathrm{RHE})\end{array}$ & $\begin{array}{c}\triangle \mathrm{E}_{1 / 2} \\
(\text { vs. } \mathrm{Pt} / \mathrm{C}, \mathrm{mV})\end{array}$ & Stability & Ref. \\
\hline meso-Fe-N-C & 0.4 & 0.846 & 22 & $12 \mathrm{mV}, 10000$ cycles* & This work \\
\hline $\mathrm{Fe} / \mathrm{N} / \mathrm{C}$ & 0.1 & 0.845 & -25 & $14 \mathrm{mV}, 8000$ cycles* & 22 \\
\hline $\mathrm{Fe}-\mathrm{N} / \mathrm{C}-155$ & 0.2 & 0.850 & 50 & $\sim 10 \mathrm{mV}, 10000$ cycles* & 23 \\
\hline $\mathrm{Fe}(0) @ \mathrm{FeNC}$ & 0.3 & 0.852 & 26 & $33 \mathrm{mV}, 5000$ cycles* & 24 \\
\hline Fe-N-DSC & 0.1 & 0.840 & 13 & $4.1 \%, 30000 \mathrm{~s}^{\# 1}$ & 25 \\
\hline Fe-NMP & 0.6 & 0.840 & 10 & N.A. & 26 \\
\hline N-Fe/N/C-CNT & \multirow[b]{2}{*}{0.6} & 0.800 & -20 & \multirow[b]{2}{*}{ N.A. } & \multirow[b]{2}{*}{27} \\
\hline $\begin{array}{c}\mathrm{S}, \mathrm{N}-\mathrm{Fe} / \mathrm{N} / \mathrm{C}- \\
\mathrm{CNT}\end{array}$ & & 0.850 & 30 & & \\
\hline $\mathrm{FeN}_{\mathrm{x}}-\mathrm{PNC}$ & 0.1 & 0.860 & 20 & $20 \mathrm{mV}, 10000$ cycles*. & 28 \\
\hline $\begin{array}{c}\mathrm{FeP}_{\mathrm{x}} / \mathrm{Fe}-\mathrm{N}- \\
\mathrm{C} / \mathrm{NPC}\end{array}$ & 0.2 & 0.860 & 20 & $14 \%, 24 \mathrm{~h}^{\# 2}$ & 29 \\
\hline
\end{tabular}

*Loss in $\mathrm{E}_{1 / 2}$, cycle numbers of $\mathrm{CV}$

\#Decreasing percent of its initial value, duration time

\#1Potential: 0.691 V vs. RHE

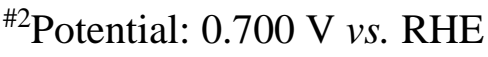


Table S2. Comparison of TOF of Fe-N-C-based catalysts in alkalion condition.

\begin{tabular}{|c|c|c|c|c|c|c|}
\hline \multirow{2}{*}{ Catalysts } & \multirow{2}{*}{$\begin{array}{c}\text { Fe } \\
\text { content }\end{array}$} & \multicolumn{2}{|c|}{$j_{k}\left(\mathrm{~mA} \mathrm{~cm}{ }^{-2}\right)$} & \multicolumn{2}{|c|}{ TOF $\left[e \cdot \operatorname{site}^{-1} \cdot \mathbf{s}^{-1}\right]$} & \multirow{2}{*}{ Ref. } \\
\hline & & (a) $0.80 \mathrm{~V}_{\mathrm{RHE}}$ & (a) $0.85 \mathrm{~V}_{\mathrm{RHE}}$ & (a) $0.80 \mathrm{~V}_{\mathrm{RHE}}$ & (a) $0.85 \mathrm{~V}_{\mathrm{RHE}}$ & \\
\hline meso-Fe-N-C & $2.90 \mathrm{wt} \%$ & 20.265 & 4.696 & 1.011 & 0.234 & $\begin{array}{l}\text { This } \\
\text { work }\end{array}$ \\
\hline $\begin{array}{c}\text { Fe-N-C-2HT- } \\
\text { 1AL }\end{array}$ & $12.00 \mathrm{wt} \%$ & $7.600 \pm 0.800$ & 1 & 0.700 & 1 & \\
\hline $\begin{array}{c}\text { Fe-N-C-3HT- } \\
\text { 2AL }\end{array}$ & $6.00 \mathrm{wt} \%$ & $20.000 \pm 0.700$ & 1 & 1.700 & 1 & \\
\hline $\begin{array}{c}\mathrm{S}, \mathrm{N}-\mathrm{Fe} / \mathrm{N} / \mathrm{C}- \\
\mathrm{CNT}\end{array}$ & 0.80 at $\%$ & 1 & 7.350 & 1 & 0.213 & 27 \\
\hline $\begin{array}{c}\mathrm{Fe}-\mathrm{N}_{4} \\
\text { SAs/NPC }\end{array}$ & $1.96 \mathrm{wt} \%$ & 1 & 7.470 & 1 & 0.432 & 31 \\
\hline
\end{tabular}

Note: 1. The estimation is based on the assumption that all the Fe atoms are participating the reaction. 2. According to the calculation formula of TOF, the specific value of TOF is calculated under specific potential, but the potetial selected in each article is different, so we only select some of the data for comparison. 
Table S3. Comparison of MEA performance for Fe-N-C-based catalysts.

\begin{tabular}{|c|c|c|c|c|c|}
\hline Catalysts & $\begin{array}{c}\text { Cat. Loading, } \\
\text { Membrane area }\end{array}$ & $\begin{array}{c}\text { Operation } \\
\text { temperature, } \\
\text { Back pressure }\end{array}$ & $\begin{array}{c}\text { Peak power } \\
\text { density }(\mathrm{mW} \\
\left.\mathrm{cm}^{-2}\right)\end{array}$ & $\begin{array}{c}\mathrm{O}_{2} \text { flow rate } \\
\text { (scem) }\end{array}$ & Ref. \\
\hline meso-Fe-N-C & $\begin{array}{c}4.0 \mathrm{mg} \mathrm{cm}^{-2} \\
1 \mathrm{~cm}^{2}\end{array}$ & $80{ }^{\circ} \mathrm{C}, 2$ bar & 584 & 500 & This work \\
\hline $\mathrm{Ce} / \mathrm{Fe}-\mathrm{NCNW}$ & $\begin{array}{c}1.0 \mathrm{mg} \mathrm{cm}^{-2} \\
5 \mathrm{~cm}^{2}\end{array}$ & $80^{\circ} \mathrm{C}, 30 \mathrm{psi}^{\top}$ & 496 & 700 & 32 \\
\hline $1.5 \mathrm{Fe}-\mathrm{ZIF}$ & $\begin{array}{c}4.0 \mathrm{mg} \mathrm{cm}^{-2} \\
5 \mathrm{~cm}^{2}\end{array}$ & $80{ }^{\circ} \mathrm{C}, 1$ bar & 360 & 200 & 33 \\
\hline $\begin{array}{c}\text { Fe-SAs/NPS- } \\
\text { HC }\end{array}$ & $\begin{array}{c}0.8 \mathrm{mg} \mathrm{cm}^{-2} \\
5 \mathrm{~cm}^{2}\end{array}$ & $\begin{array}{l}60^{\circ} \mathrm{C}, 2 \text { bar } \\
80^{\circ} \mathrm{C}, 2 \text { bar }\end{array}$ & $\begin{array}{l}333 \\
400\end{array}$ & N.A. & 34 \\
\hline $\begin{array}{c}\mathrm{Fe} / \mathrm{N} / \mathrm{C}- \\
\mathrm{ZnCl}_{2} / \mathrm{KCl}\end{array}$ & $\begin{array}{c}4.0 \mathrm{mg} \mathrm{cm}^{-2}, \\
\text { N.A. }\end{array}$ & $80^{\circ} \mathrm{C}, 2$ bar & 576 & 300 & 35 \\
\hline $\begin{array}{c}\text { Fe-Phen/CNT } \\
\text { Fe-P- } \\
\text { Phen/CNT }\end{array}$ & $\begin{array}{c}1.5 \mathrm{mg} \mathrm{cm}^{-2} \\
25 \mathrm{~cm}^{2}\end{array}$ & $80{ }^{\circ} \mathrm{C}, 2$ bar & $\begin{array}{l}420 \\
572\end{array}$ & 1200 & 36 \\
\hline $\begin{array}{c}\mathrm{Fe} / \mathrm{N} / \mathrm{C} \\
\text { nanotubes } \\
\left(800{ }^{\circ} \mathrm{C}\right) \\
\mathrm{Fe} / \mathrm{N} / \mathrm{C} \\
\text { nanotubes } \\
\left(1000^{\circ} \mathrm{C}\right)\end{array}$ & $\begin{array}{c}2.0 \mathrm{mg} \mathrm{cm}^{-2} \\
4 \mathrm{~cm}^{2}\end{array}$ & $60{ }^{\circ} \mathrm{C}, 1$ bar & 485 & 400 & 37 \\
\hline
\end{tabular}

$\overline{\bar{T}}$ psi: pounds per square inch 


\section{Supplementary References}

1. Guan, B. Y.; Yu, L.; Lou, X. W., Formation of Asymmetric Bowl-Like Mesoporous Particles via Emulsion-Induced Interface Anisotropic Assembly. J. Am. Chem. Soc. 2016, 138 (35), 11306-11311.

2. Peng, L.; Hung, C. T.; Wang, S.; Zhang, X.; Zhu, X.; Zhao, Z.; Wang, C.; Tang, Y.; Li, W.; Zhao, D., Versatile Nanoemulsion Assembly Approach to Synthesize Functional Mesoporous Carbon Nanospheres with Tunable Pore Sizes and Architectures. J. Am. Chem. Soc. 2019, 141 (17), $7073-7080$.

3. Malko, D.; Kucernak, A.; Lopes, T., In Situ Electrochemical Quantification of Active Sites in Fe-N/C Non-Precious Metal Catalysts. Nat. Commun. 2016, $7(1), 13285$.

4. Wan, X.; Liu, X.; Li, Y.; Yu, R.; Zheng, L.; Yan, W.; Wang, H.; Xu, M.; Shui, J., Fe-N-C Electrocatalyst with Dense Active Sites and Efficient Mass Transport for High-Performance Proton Exchange Membrane Fuel Cells. Nat. Catal. 2019, 2 (3), 259-268.

5.Liang, S.; Guo, H.; Shen, H.; Gong, H.; Fan, F.; Lv, M.; Thomas, T.; Liu, J.; Yang, M.; Zhao, Z., Ordered Mesoporous Carbon Assisted Fe-N-C for Efficient Oxygen Reduction Catalysis in both Acidic and Alkaline Media. Nanotechnology 2020, 31 (16), 165708.

6. Primbs, M.; Sun, Y.; Roy, A.; Malko, D.; Mehmood, A.; Sougrati, M.-T.; Blanchard, P.-Y.; Granozzi, G.; Kosmala, T.; Daniel, G.; Atanassov, P.; Sharman, J.; Durante, C.; Kucernak, A.; Jones, D.; Jaouen, F.; Strasser, P., Establishing Reactivity Descriptors for Platinum Group Metal (PGM)-free Fe-N-C Catalysts for PEM Fuel Cells. Energy Environ. Sci. 2020, 13 (8), 2480-2500.

7. Tao, L.; Wang, Q.; Dou, S.; Ma, Z.; Huo, J.; Wang, S.; Dai, L., Edge-Rich and Dopant-Free Graphene as a Highly Efficient Metal-Free Electrocatalyst for the Oxygen Reduction Reaction. Chem Commun (Camb) 2016, 52 (13), 2764-2767.

8. Xu, X.; Shi, C.; Li, Q.; Chen, R.; Chen, T., Fe-N-Doped Carbon Foam Nanosheets with Embedded $\mathrm{Fe}_{2} \mathrm{O}_{3}$ Nanoparticles for Highly Efficient Oxygen Reduction in Both Alkaline and Acidic Media. RSC Adv. 2017, 7 (24), 14382-14388.

9. Yasuda, S.; Furuya, A.; Uchibori, Y.; Kim, J.; Murakoshi, K., Iron-Nitrogen-Doped Vertically Aligned Carbon Nanotube Electrocatalyst for the Oxygen Reduction Reaction. Adv. Funct. Mater. 2016, 26 (5), 738-744.

10. Huang, X.; Yang, Z.; Dong, B.; Wang, Y.; Tang, T.; Hou, Y., In Situ Fe 2 N@N-Doped Porous Carbon Hybrids as Superior Catalysts for Oxygen Reduction Reaction. Nanoscale 2017, 9 (24), 8102-8106.

11. Martinaiou, I.; Monteverde Videla, A. H. A.; Weidler, N.; Kübler, M.; Wallace, W. D. Z.; Paul, S.; Wagner, S.; Shahraei, A.; Stark, R. W.; Specchia, S.; Kramm, U. I., Activity and Degradation Study of an Fe-N-C catalyst for ORR in Direct Methanol Fuel Cell (DMFC). Appl. Catal., B $2019,118217$.

12. Artyushkova, K., Misconceptions in Interpretation of Nitrogen Chemistry from X-Ray Photoelectron Spectra. J. Vac. Sci. Technol. A 2020, 38 (3), 031002.

13. Artyushkova, K.; Kiefer, B.; Halevi, B.; Knop-Gericke, A.; Schlogl, R.; Atanassov, P., Density Functional Theory Calculations of XPS Binding Energy Shift for Nitrogen-Containing Graphene-Like Structures. Chem. Commun. 2013, 49 (25), 2539-2541.

14. Kim, S. J.; Mahmood, J.; Kim, C.; Han, G. F.; Kim, S. W.; Jung, S. M.; Zhu, G.; De Yoreo, J. J.; Kim, G.; Baek, J. B., Defect-Free Encapsulation of Fe(0) in 2D Fused Organic Networks as a Durable Oxygen Reduction Electrocatalyst. J. Am. Chem. Soc. 2018, 140 (5), 1737-1742.

15. Liu, Q.; Guo, C.; Sun, L.; Zhou, R.; Liu, Y.; Sun, W.; Xiang, S.; Li, Y.; Si, Y.; Luo, Z., High Active-Site Availability on Fe-N-C Oxygen Reduction Electrocatalysts Derived from Iron(II) Complexes of Phenanthroline with a $\mathrm{K}_{2} \mathrm{C}_{2} \mathrm{O}_{4}$ Promoter. J. Alloys. Compd. 2019, 809, 151822.

16. Lin, L.; Zhu, Q.; Xu, A. W., Noble-Metal-Free Fe-N/C Catalyst for Highly Efficient Oxygen Reduction Reaction under both Alkaline and Acidic Conditions. J. Am. Chem. Soc. 2014, 136 (31), 11027-11033.

17. Sa, Y.J.; Seo, D.-J.; Woo, J.; Lim, J. T.; Cheon, J. Y.; Yang, S. Y.; Lee, J. M.; Kang, D.; Shin, T. J.; Shin, H. S.; Jeong, H. Y.; Kim, C. S.; Kim, M. G.; Kim, T.-Y.; Joo, S. H., A General Approach to Preferential Formation of Active Fe-N $\mathrm{x}_{\mathrm{x}}$ Sites in Fe-N/C Electrocatalysts for Efficient Oxygen Reduction Reaction. J. Am. Chem. Soc. 2016, 138 (45), 15046-15056.

18. Hong, S.; Na, Y. S.; Choi, S.; Song, I. T.; Kim, W. Y.; Lee, H., Non-Covalent Self-Assembly and Covalent Polymerization Co-Contribute to Polydopamine Formation. Adv. Funct. Mater. 2012, 22 (22), 4711-4717. 
19. Della Vecchia, N. F.; Avolio, R.; Alfè, M.; Errico, M. E.; Napolitano, A.; d'Ischia, M., Building-Block Diversity in Polydopamine Underpins a Multifunctional Eumelanin-Type Platform Tunable Through a Quinone Control Point. Adv. Funct. Mater. 2013, 23 (10), 1331-1340.

20. Delparastan, P.; Malollari, K. G.; Lee, H.; Messersmith, P. B., Direct Evidence for the Polymeric Nature of Polydopamine. Angew. Chem., Int. Ed. 2019, $58(4), 1077-1082$.

21. Liebscher, J.; Mrowczynski, R.; Scheidt, H. A.; Filip, C.; Hadade, N. D.; Turcu, R.; Bende, A.; Beck, S., Structure of Polydopamine: A Never-Ending Story? Langmuir 2013, 29 (33), 10539-10548.

22. Wu, Y.; Nagata, S.; Nabae, Y., Genuine Four-Electron Oxygen Reduction over Precious-Metal-Free Catalyst in Alkaline Media. Electrochim. Acta 2019, 319, 382-389.

23. Ye, G.; He, Q.; Liu, S.; Zhao, K.; Su, Y.; Zhu, W.; Huang, R.; He, Z., Cage-Confinement of Gas-Phase Ferrocene in Zeolitic Imidazolate Frameworks to Synthesize High-Loading and Atomically Dispersed Fe-N Codoped Carbon for Efficient Oxygen Reduction Reaction. J. Mater. Chem. A 2019, 7 (27), 1650816515.

24. Li, Z.; Wei, L.; Jiang, W.-J.; Hu, Z.; Luo, H.; Zhao, W.; Xu, T.; Wu, W.; Wu, M.; Hu, J.-S., Chemical State of Surrounding Iron Species Affects the Activity of Fe- $\mathrm{N}_{\mathrm{x}}$ for Electrocatalytic Oxygen Reduction. Appl. Catal., B 2019, 251, 240-246.

25. Huang, Z.; Pan, H.; Yang, W.; Zhou, H.; Gao, N.; Fu, C.; Li, S.; Li, H.; Kuang, Y., In Situ Self-Template Synthesis of Fe-N-Doped Double-Shelled Hollow Carbon Microspheres for Oxygen Reduction Reaction. ACS Nano 2018, 12 (1), 208-216.

26. Hossen, M. M.; Artyushkova, K.; $\quad$ Atanassov, P.; Serov, A., Synthesis and Characterization of High Performing Fe-N-C Catalyst for Oxygen Reduction Reaction (ORR) in Alkaline Exchange Membrane Fuel Cells. J. Power Sources 2018, 375, 214221.

27. Chen, P.; Zhou, T.; Xing, L.; Xu, K.; Tong, Y.; Xie, H.; Zhang, L.; Yan, W.; Chu, W.; Wu, C.; Xie, Y., Atomically Dispersed IronNitrogen Species as Electrocatalysts for Bifunctional Oxygen Evolution and Reduction Reactions. Angew. Chem., Int. Ed. 2017, 56 (2), $610-614$.

28. Ma, L.; Chen, S.; Pei, Z.; Huang, Y.; Liang, G.; Mo, F.; Yang, Q.; Su, J.; Gao, Y.; Zapien, J. A.; Zhi, C., Single-Site Active Iron-Based Bifunctional Oxygen Catalyst for a Compressible and Rechargeable Zinc-Air Battery. ACS Nano 2018, 12 (2), 1949-1958.

29. Qin, Q.; Jang, H.; Li, P.; Yuan, B.; Liu, X.; Cho, J., A Tannic Acid-Derived N-, P-Codoped Carbon-Supported Iron-Based Nanocomposite as an Advanced Trifunctional Electrocatalyst for the Overall Water Splitting Cells and Zinc-Air Batteries. Adv.Energy Mater. 2019, 9 (5), 1803312.

30. Sahraie, N. R.; Kramm, U. I.; Steinberg, J.; Zhang, Y.; Thomas, A.; Reier, T.; Paraknowitsch, J.-P.; Strasser, P., Quantifying the Density and Utilization of Active Sites in Non-Precious Metal Oxygen Electroreduction Catalysts. Nat. Commun. 2015, 6 (1), 8618.

31. Pan, Y.; Liu, S.; Sun, K.; Chen, X.; Wang, B.; Wu, K.; Cao, X.; Cheong, W.-C.; Shen, R.; Han, A.; Chen, Z.; Zheng, L.; Luo, J.; Lin, Y.; Liu, Y.; Wang, D.; Peng, Q.; Zhang, Q.; Chen, C.; Li, Y., A Bimetallic Zn/Fe Polyphthalocyanine-Derived Single-Atom Fe-N 4 Catalytic Site:A Superior Trifunctional Catalyst for Overall Water Splitting and Zn-Air Batteries. Angew. Chem., Int. Ed. 2018, 57 (28), 8614-8618.

32. Li, J.-C.; Maurya, S.; Kim, Y. S.; Li, T.; Wang, L.; Shi, Q.; Liu, D.; Feng, S.; Lin, Y.; Shao, M., Stabilizing Single-Atom Iron Electrocatalysts for Oxygen Reduction via Ceria Confining and Trapping. ACS Catal. 2020, 10 (4), 2452-2458.

33. Zhang, H.; Chung, H. T.; Cullen, D. A.; Wagner, S.; Kramm, U. I.; More, K. L.; Zelenay, P.; Wu, G., High-Performance Fuel Cell Cathodes Exclusively Containing Atomically Dispersed Iron Active Sites. Energy Environ. Sci 2019, 12 (8), 2548-2558.

34. Chen, Y.; Ji, S.; Zhao, S.; Chen, W.; Dong, J.; Cheong, W. C.; Shen, R.; Wen, X.; Zheng, L.; Rykov, A. I.; Cai, S.; Tang, H.; Zhuang, Z.; Chen, C.; Peng, Q.; Wang, D.; Li, Y., Enhanced Oxygen Reduction with Single-Atomic-Site Iron Catalysts for a Zinc-Air Battery and Hydrogen-Air Fuel Cell. Nat. Commun 2018, $9(1), 5422$.

35. Li, J.; Chen, S.; Li, W.; Wu, R.; Ibraheem, S.; Li, J.; Ding, W.; Li, L.; Wei, Z., A Eutectic Salt-Assisted Semi-Closed Pyrolysis Route to Fabricate HighDensity Active-Site Hierarchically Porous Fe/N/C Catalysts for the Oxygen Reduction Reaction. J. Mater. Chem. A 2018, 6 (32), $15504-15509$.

36. Woo, J.; Yang, S. Y.; Sa, Y. J.; Choi, W.-Y.; Lee, M.-H.; Lee, H.-W.; Shin, T. J.; Kim, T.-Y.; Joo, S. H., Promoting Oxygen Reduction Reaction Activity of Fe-N/C Electrocatalysts by Silica-Coating-Mediated Synthesis for Anion-Exchange Membrane Fuel Cells. Chem. Mater. 2018, 30 (19), 6684-6701. 
37. Ren, H.; Wang, Y.; Yang, Y.; Tang, X.; Peng, Y.; Peng, H.; Xiao, L.; Lu, J.; Abruña, H. D.; Zhuang, L., Fe/N/C Nanotubes with Atomic Fe Sites: A Highly Active Cathode Catalyst for Alkaline Polymer Electrolyte Fuel Cells. ACS Catal. 2017,7 (10), 6485-6492. 